\title{
THE GLOBALIZATION OF PRIVATE KNOWLEDGE GOODS AND THE PRIVATIZATION OF GLOBAL PUBLIC GOODS
}

\author{
Keith E. Maskus and Ferome H. Reichman*
}

\begin{abstract}
Global trade and investment have become increasingly liberalized in recent decades. This liberalization has lately been accompanied by substantive new requirements for strong minimum standards of intellectual property (IP) protection, which moves the world economy toward harmonized private rights in knowledge goods. While this trend may have beneficial impacts in terms of innovation and technology diffusion, such impacts would not be evenly distributed across countries. Deep questions also arise about whether such globalization of rights to information will raise roadblocks to the national and international provision of such public goods as environmental protection, public health, education, and scientific advance. This article argues that the globalized IP regime will strongly affect prospects for technology transfer and competition in developing countries. In turn, these nations must determine how to implement such standards in a pro-competitive manner and foster innovation and competition in their own markets. Developing countries may need to take the lead in policy experimentation and IP innovation in order to offset overly protectionist tendencies in the rich countries and to maintain the supply of global public goods in an emerging transnational system of innovation.
\end{abstract}

\section{TABLE OF CONTENTS}

I. Introduction and Conceptual Framework

A. International Public Goods and Intellectual Property Rights

B. Technology Transfer after the TRIPS Agreement

* Keith Maskus is Professor in, and Chair of, the Department of Economics at the University of Colorado, Boulder, Colorado. J. H. Reichman is the Bunyan S. Womble Professor of Law at Duke University School of Law, Durham, North Carolina. This article is based on a paper presented at the Conference on International Public Goods and Transfer of Technology Under a Globalized Intellectual Property Regime, held at Duke University School of Law on 4-6 April 2003. 
II. Re-Regulating the Global Marketplace to Protect Knowledge as a Private Good

A. Legal and Organizational Impediments to the Creation and Diffusion of Knowledge Goods

1. Preserving Temporary Competitive Advantages with International Intellectual Property Standards

2. Instability and Loss of Balance in Developed Intellectual Property Regimes

3. Exporting a Dysfunctional System to the Rest of the World?

B. Impact of Intellectual Property Standards on the Reserved Welfare Powers of WTO Members

III. Balancing Public and Private Interests in an Emerging Transnational System of Innovation

A. Developing Countries as Defenders of the Competitive Ethos

1. A Moratorium on Stronger Intellectual Property Standards

2. An Institutional Infrastructure for Reconciling Existing IPRs with National and Regional Systems of Innovation

B. Maintaining the Supply of Knowledge as a Global Public Good

1. Dynamic Properties of Knowledge as a Global Public Good

2. Nurturing a Transnational System of Innovation

\section{INTRODUCTION AND CONCEPTUAL FRAMEWORK}

Economists studying international trade remain optimistic about the ability of liberal trade policies and integration into the global economy to encourage growth and raise people in poor countries out of poverty. For example, in a recent speech at Duke University, the World Bank's former Chief Economist, Nicholas Stern, showed figures depicting a significant rise in per capita GDP across developing countries as a whole in recent years. ${ }^{1}$ His point was that, despite other obstacles to growth, more open markets, improved governance, and increasing entrepreneurial activity were generating a positive impact in poor countries. Even Oxfam, an organization that has been highly critical of globalization, in a recent report recognized the role that open trade regimes have played in providing greater opportunities for the impoverished to benefit from extended markets. ${ }^{2}$

${ }^{1}$ Nicholas Stern, 'International Action for Fighting Poverty: An Historic Opportunity', Lecture given at Duke University (2 September 2003). See also J. H. Reichman, 'Managing the Challenge of a Globalized Intellectual Property Regime', paper presented to the Second Bellagio Meeting on Intellectual Property and Development, UNCTAD/ICTSD, 17-20 September 2003 (discussing Stern's thesis); David Dollar and Aart Kraay, 'Trade, Growth, and Poverty', manuscript, Development Research Group, the World Bank, 2001 (on file with the authors).

2 Oxfam, Rigged Rules and Double Standards: Trade, Globalisation, and the Fight Against Poverty (2002). 
In general, we share this confidence but argue that a considerable qualification needs to be made. Open trade and investment regimes work best to encourage development and structural transformation where markets for information and technology transfer are competitive in ways that permit innovation, learning, and diffusion to flourish. Put differently, for poor countries to take advantage of globalization opportunities, they need to absorb, implement, and even develop new technologies.

An inability to do so risks increasing fragmentation and divergence from the technology-driven world economy rather than growing integration and convergence. Indeed, one could have applied Stern's optimistic description to the centrally planned economies of Eastern Europe over the period 19501975. They had high rates of savings (even if forced) and capital accumulation, and were generating apparently high growth. However, these economies failed to establish effective innovation systems: they lacked skills, infrastructure, and the entrepreneurial culture that could encourage competition and learning, and they relied instead on protected and inefficient industrial behemoths. These establishments could not cope well with competitive pressures dependent upon economic liberalization, and their economies stagnated.

A different kind of technological roadblock may be facing developing countries in their efforts to integrate into the world economy. A central element in global policy is the ever-increasing levels of required protection for information, technology, and creative activity through exclusive intellectual property rights (IPRs). This trend is most evident in the Agreement on TradeRelated Aspects of Intellectual Property Rights (TRIPS Agreement), a component of the Agreement Establishing the World Trade Organization (WTO). ${ }^{3}$ The TRIPS Agreement sets out a comprehensive set of minimum protection standards that Members must observe and enforce with respect to patents, copyrights, trademarks, geographical indications, confidential business information, industrial designs, and integrated circuit designs. ${ }^{4}$ Even stronger rules are being widely established through bilateral and preferential trade agreements that the United States and the European Union have negotiated with developing countries. ${ }^{5}$ Recent agreements reached at the

\footnotetext{
${ }^{3}$ Marrakesh Agreement Establishing the World Trade Organization [hereinafter WTO Agreement], Annex 1C, Agreement on Trade-Related Aspects of Intellectual Property Rights, 15 April 1994, 33 I.L.M. (1994) 81 [hereinafter TRIPS Agreement].

${ }^{4}$ See e.g., J. H. Reichman, 'Universal Minimum Standards of Intellectual Property Protection under the TRIPS Component of the WTO Agreement', in C. M. Correa and A. Yusuf (eds), Intellectual Property and International Trade: The TRIPS Agreement (1998) at 21-88; see generally Jayashree Watal, Intellectual Property Rights in the WTO and Developing Countries (2001); Carlos M. Correa, Intellectual Property Rights, the WTO and Developing Countries (2000).

5 See e.g., Peter Drahos, 'Developing Countries and International Intellectual Property StandardSetting', 5 J. World Intell. Prop. (2002) 765; Keith E. Maskus, 'Strengthening Intellectual Property Rights in Lebanon', in B. Hoekman and J. Zarrouk (eds), Catching up with the Competition: Trade Opportunities and Challenges for Arab Countries (2000), at 251-52.
} 
World Intellectual Property Organization (WIPO) on the electronic transmission of works protected by copyrights or related rights ${ }^{6}$ and ongoing negotiations at that organization on harmonization of patent rights ${ }^{7}$ continue the drive to ratchet upward global protection regimes.

The evolving system of stronger private rights in new technologies could lead to global gains in innovation and additional market-mediated information transfers to developing countries. ${ }^{8}$ Indeed, one can argue that the harmonization of IPRs provides developing countries with tools for technology-driven development that they would otherwise lack. By wisely managing these tools, developing countries may obtain additional foreign direct investment (FDI), more licensing of high-quality technologies, and more access to advanced knowledge goods.

We do not dispute the potential for such outcomes, although we believe that the scope for achieving them in different nations much depends on innovation policies and other complementary factors. ${ }^{9}$ In this introductory article, however, we raise some fundamental concerns about the implications of the new regime for the ability of firms in developing countries to break into global - or even domestic - markets and compete effectively. It seems increasingly likely that stronger global IPRs could reduce the scope for such firms to acquire new, and even mature, technologies at manageable costs. The natural competitive disadvantages of follower countries may become reinforced by a proliferation of legal monopolies and related entry barriers that result from global minimum intellectual property (IP) standards. Such external restraints on competition could consign the poorest countries to a quasi-permanent status at the bottom of the technology and growth ladder.

We find it ironic that, as tariffs, quotas, and other formal barriers to trade are dismantled, there has been a strong push to re-regulate world technology markets. Although the ratcheting up of global IPRs could adversely affect the growth prospects of developing countries, these nations have so far exerted little influence on standard-setting exercises. Indeed, the progressive reregulation of world markets for knowledge goods is not driven by a broad consensus of economic agents in the developed world. Rather, pressures to elevate IP norms are exerted by powerful private interests whose lobbying

${ }^{6}$ WIPO Copyright Treaty, adopted by the Diplomatic Conference on 20 December 1996, WIPO Doc. CRNR/DC/94 (23 December 1996); WIPO Performances and Phonograms Treaty, adopted by the Diplomatic Conference on 20 December 1996, WIPO Doc. CRNR/DC/95 (23 December 1996); see generally Pamela Samuelson, 'The U.S. Digital Agenda at WIPO', 37 Va. J. Int'l L. (1997) 369.

7 WIPO, Standing Committee on the Law of Patents, Draft Substantive Patent Law Treaty, Ninth Session, Geneva, 12-16 May 2003, SCP/9/2, available at http://www.wipo.int/scp/en/documents/ session_9/pdf/scp9_2.pdf (visited 5 January 2004) [hereinafter Draft Patent Law Treaty]. See also John H. Barton, 'Issues Posed by a World Patent System' [this symposium].

${ }^{8}$ Keith E. Maskus, Intellectual Property Rights in the Global Economy (Washington, DC: Institute for International Economics, 2000), at 109-42.

9 Maskus, above n 8, at 199-232. 
activities hold sway in legislative and regulatory initiatives in rich countries and international forums.

These efforts are largely detached from the traditional goal of domestic IP systems to strike a balance between commercial profitability and publicinterest concerns. To the extent that this imbalance makes it harder for entrepreneurs in developing countries to obtain inputs they need to compete in the production of knowledge goods, these countries could discover that the re-regulated global economy had in effect removed the rungs on which they could advance. ${ }^{10}$

As private interests take precedence over public concerns, moreover, we argue that the proliferation of exclusive rights could raise fundamental roadblocks for the national and global provision of numerous other public goods, including scientific research, education, health care, biodiversity, and environmental protection. ${ }^{11}$ The architects of the new system evidently have paid little attention to these issues, believing that a clear specification of strong property rights could establish appropriate incentives for private development of modalities to advance these and other public activities. In our view, the greater likelihood is that the privatization of public-interest technologies could in many cases erect competitive barriers, raise transactions costs and produce significant anti-commons effects, which tend to reduce the supply of public goods related to innovation as such, and also to limit the capacity of single states to perform essential police and welfare functions not otherwise available from a decentralized international system of governance. ${ }^{12}$

In Part I of this article, we set out some basic principles and observations regarding the provision of global public goods (GPG) and how that provision is implicated by the increasingly internationalized system of IP protection. In Part II, we evaluate legal and organizational impediments to the creation and diffusion of knowledge goods in a re-regulated global economy. In particular, we point out that unbalanced IP regimes in developed countries may be triggering counterproductive results and the concomitant risk that efforts to lock in the temporary competitive advantages of powerful technology cartels may raise costs for the developing world.

In Part III, we consider the seemingly paradoxical possibility that, as developing countries experiment with their own IP regimes, and with associated regimes of competition law and innovation promotion, they might

10 See e.g., International Intellectual Property Rights and Development Policy 8-9, 11-27 (Commission on Intellectual Property Rights (CIPR), 2002) [hereinafter CIPR].

11 See below text accompanying nn 100-127.

12 In this article, we offer only an overview of essential concepts regarding global public goods and their interaction with IP protection. These issues are covered more extensively in other treatments. See e.g., Peter Drahos, 'The Regulation of Public Goods' [this symposium]. For an extensive discussion of the concepts and problems of provision and distribution of such goods, see Inge Kaul et al. (eds), Providing Global Public Goods: Managing Globalization (New York: United Nations Development Program, 2003) [hereinafter Providing GPG]. 
re-inject a needed global stimulus to dynamic competition. They could also contribute to the evolution of national and regional strategies to maintain the supply of other essential public goods that has been compromised by the crosscutting effects of efforts to privatize the creation and distribution of knowledge and information as such.

\section{A. International public goods and intellectual property rights}

Global public goods might usefully be defined as those goods (including policies and infrastructure) that are systematically underprovided by private market forces and for which such under-provision has important international externality effects. ${ }^{13}$ The concept that a good is 'public' stems from a combination of nonrivalry in consumption and non-excludability in use. ${ }^{14}$ An item is nonrival if its use by one actor does not restrict the ability of another actor to benefit from it as well. A good is non-excludable to the extent that unauthorized parties ('free riders') cannot be prevented from using it.

Classic examples include national defense, environmental protection, and investments in new technical information. Each of these endeavors generates results that are essentially nonrival and at least partially nonexcludable. In consequence, private markets would not provide them at all or would do so at deficient levels relative to those demanded by citizens. A role for government thus arises to resolve this market failure.

Those concerned about the efficient provision of public goods must address three fundamental issues. ${ }^{15}$ First, what are the optimal levels of the various goods to be supported? The answer depends on the underlying demand for such goods, and it may be difficult to reveal the preferences of citizens accurately. Second, how are the desired goods to be provided? Note that public policies may provide goods directly through taxes, subsidies, and public production. Alternatively, policies may indirectly provide public goods through such regulations as competition policy, intellectual property rights, and price controls.

For example, IPRs provide a second-best resolution of the excludability also called appropriability - problem inherent in developing knowledge goods,

13 An 'externality effect' means that a failure to provide the public good imposes costs on third parties. For example, pollution arising in some countries may affect health status in others, or financial volatility in one nation may generate follow-on fragility elsewhere. In general, national policymakers are not likely to consider the well-being of foreign citizens in setting their own policies regarding public goods, which is why GPG require some form of global coordination. See Providing GPG, above n 12; Daniel G. Arce, 'Leadership and the Aggregation of International Collective Action', 53 Oxford Economic Papers (2001) at 114-37.

${ }^{14}$ Economic analysis of public goods has a long standing in the literature. See Paul A. Samuelson, 'The Pure Theory of Public Expenditure', 36 Review of Economics and Statistics (1954) 387-89; Todd Sandler, Collective Action: Theory and Applications (1992).

15 See Providing GPG, above n 12 at 36-40. 
which could otherwise be distributed at the marginal cost of making copies. ${ }^{16}$ To the extent that such rights elicit benefits from investment that exceed these social costs, they may be welfare enhancing over either market-driven solutions or pure public provision and distribution.

A third question for policymakers is to determine the best jurisdictional level for providing public goods. As a general rule, the more localized the need, the narrower should be the jurisdiction. Thus, police, public schools, and voting processes are typically seen as local obligations under United States law and practice. National defense, macroeconomic policy, and foreign policy are federal obligations.

How to organize the provision of GPG without adequate international mechanisms has become a difficult and pressing question in recent years. In practice, this function has been left largely to national or sub-national authorities. Because there are international spillover impacts, however, reliance on national provision likely fails to meet global needs efficiently or equitably. Approaches to providing GPG are required at the international level because national regimes generally disregard cross-border externalities and the resulting need for policy coordination.

Many critical public goods have become increasingly global in their effects and supply needs. ${ }^{17}$ It is fair to say that, whereas analysis of the need for integrated systems has a long history, the actual organization, provision and distribution of GPG are at an early and critical stage. This situation is well illustrated by the emerging global system of IP protection. By long tradition, IPRs were constituted as a national policy prerogative, with relatively little attention paid to coordinating standards across countries. However, wide variations in national regulations can have significant international static and dynamic externalities. ${ }^{18}$

For example, recent economics literature points to several reasons why, acting on their own interests, countries would tend to protect new technology and product development at a level that is lower than would be globally optimal. ${ }^{19}$ The main reason is that some of the gains from innovation accrue to consumers and users in other countries, a benefit that framers of IPRs would not take into account in setting domestic standards. Countries with limited innovation capacities would logically free ride on foreign $\mathrm{R} \& \mathrm{D}$ investments by offering only limited technology protection. Some means of international coordination, perhaps within the ambit of the WTO, thus

\footnotetext{
16 See Maskus, above n 8, at 36-38.

17 See Providing GPG, above n 12.

18 Keith E. Maskus, 'Regulatory Standards in the WTO: Comparing Intellectual Property Rights with Competition Policy, Environmental Protection, and Core Labor Standards', 1 World Trade Review (2002) 135-52.

19 Philip McCalman, 'National Patents, Innovation, and International Agreements', 11 Journal of International Trade and Development (2002) 1-14; Gene M. Grossman and Edwin L.-C. Lai, 'International Protection of Intellectual Property', manuscript, 2002; Suzanne Scotchmer, 'The Political Economy of Intellectual Property Treaties', manuscript 2002.
} 
arguably would move global standards closer to the optimum by elevating incentives to invest.

To be sustainable, however, this coordination should take into account the development and social needs of different economies. In principle, this objective calls for a mix of differential and flexible standards, along with compensatory side payments to induce free riders to adopt and enforce stronger IPRs.

To be sure, there is some flexibility permitted developing countries in implementing the TRIPS standards. ${ }^{20}$ Yet, even the minimum TRIPS requirements may overly burden poor nations in some circumstances. Furthermore, to benefit from residual flexibilities requires a degree of legal and regulatory expertise that may exceed the capacity of many countries for the foreseeable future. While the WTO Agreement offers some scope for implicit side payments through greater market access in developed countries for exports from developing countries, progress in achieving such access has been uneven. ${ }^{21}$ Thus, serious questions arise as to the sustainability of the attempt in TRIPS to resolve the international externality aspects of protecting new knowledge goods.

An additional criticism leveled at the emerging IPR system is that the agenda for increasing protection has been articulated and pushed by richcountry governments effectively representing the commercial interests of a limited set of industries that distribute knowledge goods. Even within some developed countries, the tendency to espouse a protectionist IP agenda seems more a reflection of policy capture than a reasoned attempt to balance domestic needs, and the long-term effects on real innovation have yet to be ascertained. At the global level, the virtual inability to date of public-minded interest groups to affect this agenda raises further questions about the sustainability of TRIPS and other elements of the system. ${ }^{22}$

If the initial impetus for a trade-related intellectual property initiative was to prevent wholesale duplication of high-tech products, the TRIPS Agreement went well beyond that objective. Whether it strikes an appropriate balance between the needs of developers, users, and public authorities on a global scale remains open to question. At least in the short run, it seems likely to shift the rules sharply in favor of IP developers, ${ }^{23}$ while the potential for long-term gains for the poorest countries seems cloudy at best. ${ }^{24}$

${ }^{20}$ J. H. Reichman, 'From Free Riders to Fair Followers: Global Competition under the TRIPS Agreement', 29 N.Y.U. J. Int'l L. \& Pol. (1997) 11.

21 See e.g., World Bank, Global Economic Prospects and the Developing Countries 2002 at 37-64 (2001).

22 See e.g., World Bank, above n 21, at 145-49 (2001); Carlos M. Correa, 'Internationalization of the Patent System and New Technologies', 20 Wisconsin Int'l L. J. (2002) 523, 544-50.

23 Philip McCalman, 'Reaping What you Sow: An Empirical Analysis of International Patent Harmonization', 55 J. Int'l Economics (2001) 161-86.

24 Maskus, above n 8; Pamela J. Smith, 'How Do Foreign Patent Rights Affect U.S. Exports, Affiliate Sales, and Licenses?', 55 J. Int'l Economics (2001) 411-40. 
We have suggested that the emerging international IP system bears characteristics of a GPG but that it seems flawed in execution and design. Moreover, this regime influences the ability of governments to provide other public goods. First, TRIPS constrains them from pursuing certain avenues for promoting imitation, innovation, and related social policies. Second, stronger private rights in information may raise roadblocks against deploying new technologies that could help improve the provision of environmental protection, health care, biological diversity, and basic scientific research. These topics are examined below in Part II.

\section{B. Technology transfer after the TRIPS Agreement ${ }^{25}$}

The international flow of technological information and its successful integration into domestic production and management processes are central to the ability of firms in developing countries to compete in the global economy. Technological change is a principal source of sustained growth in living standards and is essential for the transformation and modernization of economic structures. In most instances, developing countries find it cheaper and faster to acquire foreign technologies than to develop them with domestic resources. Such technologies may 'spill over' into wider improvements in productivity and follow-on innovation in the domestic economy.

International technology transfer (ITT) is a comprehensive term covering mechanisms for shifting information across borders and its effective diffusion into recipient economies. It refers to numerous complex processes, which range from innovation and international marketing of technology to its absorption and imitation. There are also many different channels through which technology may be transferred. One major conduit consists of trade in goods, especially capital goods and technological inputs. A second is foreign direct investment (FDI), which generally transfers technological information that is newer or more productive than that available from local firms. A third is technology licensing, which may occur either within firms or between unrelated firms. Licenses typically involve the purchase of production or distribution rights and the technical information and know-how required to exploit them. ${ }^{26}$

There are also important non-market channels of ITT. Perhaps most significant is the process of imitation through product inspection, reverse engineering, and trial and error. A related mechanism is triggered when technical and managerial personnel leave a firm and start a rival firm based on

25 This section draws on Keith E. Maskus, 'Encouraging International Technology Transfer', draft report to UNCTAD/ICTSD, 2003.

26 James R. Markusen and Keith E. Maskus, 'General Equilibrium Approaches to the Multinational Firm: A Review of Theory and Evidence', in K. Choi and J. Harrigan (eds), Handbook of International Trade (2003) at 320-49; A. Arora et al., Markets for Technology: The Economics of Innovation and Corporate Strategy (2001), at 115-42. 
information learned in the original location. Still another means is to study information available from patent applications. Thus, patents provide both a direct source of technology transfer, through FDI and licensing, and an indirect source through legally regulated disclosures. Indeed, 'trade in ideas' is a significant factor in world economic growth, and developing economies could gain considerably more access to foreign technologies as international firms take out patents in their locations. ${ }^{27}$ Nevertheless, this benefit remains dependent on local abilities to learn from incoming technological information, and on the diffusion practices or strategies of technology-exporting firms.

Much knowledge appears to be transferred through the temporary migration of students, scientists, and managerial and technical personnel to universities, laboratories, and conferences located mainly in the developed economies. Finally, technical information may be available from the public domain, making it free for taking, or from a research commons accessible with certain restrictions. $^{28}$

International markets for trading technologies are inherently subject to failure due to distortions attributable to concerns about appropriability, problems of valuing information by buyers and sellers, and market power, all strong justifications for public intervention at both the domestic and global levels. Technology developers are interested in reducing the costs and risks of making transfers, along with protecting their rights to profit from them. They argue that effective protection and policy supports for markets are necessary to increase the willingness of innovative firms to provide knowledge about their production processes to firms in developing countries. Technology importers are interested in acquiring knowledge and products at minimal cost. Some observers argue that this objective is best met by limiting the exclusive rights to exploit technology. ${ }^{29}$

27 Jonathan Eaton and Samuel Kortum, 'Trade in Ideas: Patenting and Productivity in the OECD', 40 J. Int'l Economics (1996) 251-78.

28 See e.g., J. H. Reichman and Paul Uhlir, 'A Contractually Reconstructed Research Commons for Scientific Data in a Highly Protectionist Intellectual Property Environment', 66 Law \& Contemp. Probs. (2003) 315 [hereinafter A Contractually Reconstructed Research Commons]. See generally J. M. Esanu and Paul Uhlir (eds), The Role of Scientific and Technical Data and Information in the Public Domain (National Research Council, 2003) [hereinafter Role of Scientific and Technical Data].

29 Theory favoring IPRs may be found in I. Horstmann and J. R. Markusen, 'Licensing versus Direct Investment: A Model of Internalization by the Multinational Enterprise', 20 Canadian Journal of Economics (1987) 464-81; A. Arora, 'Contracting for Tacit Knowledge: The Provision of Technical Services in Technology Licensing Contracts', 50 Journal of Development Economics (1996) 23356. For a critical view, see Carlos M. Correa, 'Can the TRIPS Agreement Foster Technology Transfer to Developing Countries?', in Keith Maskus and J. H. Reichman (eds), International Public Goods and Transfer of Technology under a Globalized Intellectual Property Regime (Cambridge University Press, forthcoming (2004)) [hereinafter International Public Goods and Intellectual Property]. 
While the close and complex relationships between intellectual property rights and ITT cannot be fully discussed here, ${ }^{30}$ it is useful to consider some of the main impacts, both positive and negative, that stronger global IPRs may have on international information flows. First, the preponderance of econometric studies suggests that market-mediated flows of technology respond positively to the strengthening of patent laws across countries. This finding applies to international trade flows, especially in patent-sensitive industries and capital goods, as regards patents in middle-income and large developing countries. ${ }^{31}$ However, trade flows to poor countries seem unresponsive to patent laws. Similarly, recent studies of patents and inward FDI find positive impacts on more advanced and larger developing countries, but not on poor and small countries. ${ }^{32}$ Licensing volumes between US firms and unrelated concerns in larger developing countries also expand with the rigor of local patent regimes. ${ }^{33}$

A reasonable interpretation of these findings is that there are threshold effects in market-based licensing. Economies with low incomes and limited technological capacity present neither attractive markets nor a competitive imitation threat. Because their intellectual property regimes are not particularly important in attracting ITT, it seems unlikely that the standards implemented in compliance with TRIPS will encourage additional technology transfer to the poorest countries. However, at higher incomes and technological capacities, IPRs become an important factor in this regard, even though they are only one of a list of variables that influence ITT. Other important factors include effective infrastructure, efficient governance, market size and growth, and proximity to suppliers and demanders. ${ }^{34}$

The literature also suggests that stronger patent rights may be expected to raise considerably the rents earned by international firms as patents become more valuable, with the result that firms in developing countries would pay more for the average inward protected technology. ${ }^{35}$ Expansion of breadth, scope, and length of patents would tend to amplify this result. Thus, there are countervailing impacts in middle-income countries: higher volumes of ITT

30 See e.g., Keith E. Maskus, 'The Role of Intellectual Property Rights in Encouraging Foreign Direct Investment and Technology Transfer', 9 Duke J. Compar. \& Internat'l L. (1998) 109-61; Kamal Saggi, International Technology Transfer: National Policies, International Negotiations, and Multilateral Disciplines, report to Commonwealth Secretariat, 2003.

31 See Smith, above n 24; Keith E. Maskus and Mohan Penubarti, 'How Trade-Related Are Intellectual Property Rights?', 39 J. Int'l Economics (1995) 227-48.

32 Smith, above n 24; Maskus, above n 8.

33 Guifang Yang and Keith E. Maskus, 'Intellectual Property Rights and Licensing: An Econometric Investigation', 127 Weltwirtschaftliches Archiv (2001) 58-79; Michael Nicholson, 'Intellectual Property Rights and International Technology Transfer: The Impact of Industry Characteristics', US Federal Trade Commission, manuscript, 2002.

${ }^{34}$ Markusen and Maskus, above n 26.

35 McCalman, above n 19; The World Bank, above n 21, at 132-34. 
but increased payments per unit of technology. Moreover, recipient countries are more likely to benefit where the supply of technologies is competitive and local firms are capable of adapting them effectively into production processes. ${ }^{36}$

While the evidence supports the claim that TRIPS standards could enhance ITT (at least into the larger and more advanced developing economies) through better performing technology markets, it should be weighed against national historic experience. Few now-developed economies underwent significant technological learning and industrial transformation without the benefit of weak intellectual property protection. ${ }^{37}$ A good example is Japan, which from the 1950s through the 1980s pursued an industrial property regime that favored small-scale innovation, adaptation and diffusion, and the licensing of new technologies. Key features of this system included pre-grant disclosure, rapid opposition to patent grants, narrow patent claims, local reliance on utility models and advantages for licensing. ${ }^{38}$ Another example is South Korea, which in the 1970s encouraged domestic firms to acquire and adapt mature technologies available on international markets for purposes of developing local innovation capacities. ${ }^{39}$

The extent to which the emerging global IP regime may be expected to enhance or impede ITT thus poses a complicated question. Answering it is made even harder because technology transfer across borders involves a mixture of private activities and public measures of encouragement (or discouragement). This mixture varies in cost and efficiency by sector, country, and over time, which suggests that globalized IP protection could have both complex and sub-optimal effects unless accompanied by appropriate complementary policy approaches. ${ }^{40}$

The new system raises entry barriers for firms and competition in the poorest countries, while even the middle-income nations find their scope of action limited. Market distortions due to misuses of intellectual property rights may also be harder to detect or police in developing than in developed countries. Moreover, new or relatively untested forms of intellectual property protection that choke access to upstream information inputs - including scientific and technical data as such - could narrow access to the research

36 Maskus, above n 25.

37 Z. Khan, 'Intellectual Property and Economic Development: Lessons from American and European History', Commission on Intellectual Property Rights, background paper 1A, 2002; N. Kumar, 'Intellectual Property Rights, Technology and Economic Development: Experiences of Asian Countries', Commission on Intellectual Property Rights background paper 1B, 2002.

38 Janusz A. Ordover, 'A Patent System for both Diffusion and Exclusion', 5 J. Economic Perspectives (1991) 43-60.

39 Linsu Kim, 'Technology Transfer and Intellectual Property Rights: Lessons from Korea's Experience', UNCTAD/ICTSD working paper, 2002.

${ }^{40}$ Maskus, above n 8, at 143-60. 
commons and limit other transfer mechanisms, with incalculable long-term effects on ITT as it used to occur. ${ }^{41}$

In our view, governments in developing countries need to be pro-active in ensuring that the net effect of expanded IP protection is to enhance access to technology and to encourage its domestic adaptation and diffusion. Potential gains in dynamic competition are reason enough for this approach. An additional important factor is that tightened protection raises significant questions regarding the ability to access international technology and information to improve the provision of broader public goods. In the rest of this article we explore these issues in more detail.

\section{RE-REGULATING THE GLOBAL MARKETPLACE TO PROTECT KNOWLEDGE AS A PRIVATE GOOD}

One paradox of an increasingly global economy is that it ultimately requires collective action to further enhance the social benefits of free competition in an unruly marketplace that the General Agreement on Tariffs and Trade (GATT) and the Agreement Establishing the World Trade Organization (WTO) have progressively liberated from state-imposed barriers to trade. ${ }^{42}$ Who should take responsibility for this regulatory task in the absence of any duly constituted global governance authority and how to identify measures that would actually promote global welfare without creating disguised barriers to trade remain daunting problems for a decentralized international system. ${ }^{43}$

Nowhere are these tensions more acute than in the knowledge goods sector of the world economy, a sector that is the most dynamic of all in terms of potential growth and yet partially resistant to any consensus-based economic analytical framework. Here, according to classical intellectual property theory, knowledge begins life as a public good available to all and as an input into the generation of additional knowledge. It subsequently becomes artificially scarce as states grant IPRs to stimulate investment in the production of private knowledge goods. The resulting tensions between the long-term

41 See e.g., Rebecca S. Eisenberg, 'Bargaining over the Transfer of Proprietary Research Tools: Is this Market Failing or Emerging?', in Rochelle Dreyfuss et al. (eds), Expanding the Boundaries of Intellectual Property: Innovation Policy for the Knowledge Society (2001) 223-49 [hereinafter Expanding the Boundaries of IP]; Arti Kaur Rai, 'Regulating Scientific Research: Intellectual Property Rights and the Norms of Science', 94 Northwestern U.L. Rev. (1999) 77; J. H. Reichman, 'Database Protection in a Global Economy', 2002 Revue Internationale de Droit Economique (2002) 455-504; J. H. Reichman and Pamela Samuelson, 'Intellectual Property Rights in Data?', 50 Vand. L. Rev. (1997) 51.

42 Multilateral Agreements on Trade in Goods, 15 Apr. 1994, WTO Agreement, Annex 1A, 33 I.L.M. (1994) 1154 [hereinafter GATT 1994]; WTO Agreement, above n 3.

43 While the extent and degree of regulation that is needed remains controversial, even the most laissezfaire economists recognize problems attributed to market failures, market distortions, and other factors that decrease overall efficiency and welfare. See, e.g., Maskus, above nn 8 and 18. Others stress concerns about potential 'races to the bottom' in regulatory standards. See, e.g., Joseph Stiglitz, Globalization and Its Discontents (2002). 
benefits of these legal monopolies, which tend to elevate the level of competition over time,${ }^{44}$ and the social costs of restraining competition in the meanwhile ${ }^{45}$ are recognized in Article XX(d) of the GATT itself. ${ }^{46}$ This provision, which generally assigns responsibility for enacting IPRs to the WTO Members' domestic legislatures, admonishes them to observe a criterion of reasonable necessity and to avoid 'disguised restriction[s] on international trade'. ${ }^{47}$

\section{A. Legal and organizational impediments to the creation and diffusion of knowledge goods}

Drawing the lines between knowledge goods accessible to all and those subject to private property rights has always been a delicate, controversial, and economically uncertain task in even the most developed economies. Periods of relatively weak and relatively strong levels of protection have alternated over time, often at fairly short intervals, with little consensus in law or economics about the cumulative lessons to be learned. How to ensure that the social benefits of maximizing investment in current innovation are not offset by the social costs of deterring future innovation and impeding current competition is no clearer today than it was 50 years ago. ${ }^{48}$ The question has become especially difficult to answer with regard to newer, cutting-edge technologies that obstinately refuse to behave like the traditional technologies of the industrial revolution. ${ }^{49}$

Today, moreover, the regulation of knowledge goods in national markets impinges on the provision of other public goods - health, education, scientific

44 M. Lehman, 'The Theory of Property Rights and the Protection of Intellectual and Industrial Property', 16 Int'l Rev. Indus. Prop. \& Copyright (IIC) (1985) 525; Edmund Kitch, 'Nature and Function of the Patent System', 30 J. L. \& Econ. (1977) 265.

45 Hanns Ullrich, 'Expansionist Intellectual Property Protection and Reductionist Competition Rules: A TRIPS Perspective' [this symposium].

46 GATT 1994, above n 42, art. XX(d).

47 Id. This provision is, of course, subject to subsequent treaties, notably the TRIPS Agreement, which further limits states' rights. Nevertheless, the pro-competitive mandate of this provision, taken in the larger context of reserved powers under GATT art. XX generally, remains of cardinal importance to the meshing of private and public goods in further international regulation. See below text accompanying nn 124-25.

48 See e.g., James Boyle, Shamans Software and Spleens: Law and the Construction of the Information Society (1996) 25-46; John H. Barton, 'The Economics of TRIPS: International Trade in Information-Intensive Products', 33 Geo. Wash. Int'1 L. Rev. (2001) 473; Roberto Mazzoleni and Richard R. Nelson, 'Economic Theories About the Benefits and Costs of Patents', 32 Journal of Economic Issues (1998) 1031.

49 See e.g., Arti K. Rai, 'Fostering Cumulative Innovation in the Biopharmaceutical Industry: The Role of Patents and Antitrust', 16 Berkeley Tech. L. J. (2001) 813; James Boyle, 'Enclosing the Genome: What the Squabbles over Genetic Patents Could Teach Us', in F. Scott Kieff (ed), Perspectives on Properties of the Human Genome Project (2003), at 97-124; J. H. Reichman, 'Saving the Patent System from Itself: Informal Reflections on Systemic Problems Afflicting Developed Intellectual Property Regimes', in Perspectives on Properties of the Human Genome Project, above at 289-304. 
research, agriculture and the environment - in ways that were virtually unknown to previous generations. The centrality of innovation in dynamic developed economies has fostered a process of 'enclosure' and privatization that increasingly threatens the provision of those other public goods that citizens take for granted and identify with the very exercise of state sovereignty. ${ }^{50}$

When these unresolved tensions between public and private interests in the production of knowledge goods are transferred from their territorial base in nation states to the nascent world market, they become far more acute. This follows because the stakes are much higher, ${ }^{51}$ empirical evidence with which to assess the conflicting claims of high and low protectionists remains scarce, and nations have varying economic interests. The adverse effects of these uncertainties are then made worse by another paradox of the international trading system that one of us emphasized at the start of the Uruguay Round. Here we refer to the tendency of rich countries, that traditionally urged free competition on the rest of the world, to demand strong legal monopolies to protect private knowledge goods in international trade, and the tendency of poor countries to want unbridled competition with respect to these same knowledge goods, most of which are produced at great cost in the technologyexporting countries. ${ }^{52}$

\section{Preserving temporary competitive advantages with international intellectual property standards}

To understand why new distortions in the global market for knowledge goods seem to crop up faster than the old ones disappear, it is well to recognize that there is even less consensus among economists about how to regulate the global market for knowledge goods than exists in successful national markets, and that these uncertainties are aggravated by inequalities between rich and poor nations. The need to set standards ex ante - in order to reduce the public good character of facts, ideas, discoveries, and research results in favor of developing private knowledge goods - then compounds all the governance problems that beset transnational regulatory exercises in general. ${ }^{53}$

50 See e.g., James Boyle, 'The Second Enclosure Movement and the Construction of the Public Domain', 66 Law \& Contemp. Probs. (2003) 33 [hereinafter Boyle, 'Second Enclosure Movement').

51 See e.g., Joseph Stiglitz, 'Knowledge as a Public Good', in Inge Kaul et al. (eds), Global Public Goods: International Cooperation in the 21st Century (1999); Paul David, 'The Political Economy of Public Science', in Helen Lawton Smith (ed), The Regulation of Science and Technology (2001) 38.

52 See e.g., J. H. Reichman, 'Intellectual Property in International Trade: Opportunities and Risks of a GATT Connection', 22 Vand. J. Transnat'l L. (1989) 747 [hereinafter Reichman, 'GATT Connection'].

53 See e.g., Paul David, 'Koyaanisquatsi in Cyberspace: The Economics of an Out-of-Balance Regime of Private Property Rights in Data and Information', in International Public Goods and Intellectual Property, above n 29; Mark Lemley, 'Ex Ante versus Ex Post Justification for Intellectual Property', working paper (2003); Frederick Abbott, 'The Future of IPRs in the Multilateral Trading System', in C. Bellman, G. Dutfield, and R. Melendez-Ortiz (eds), Trading in Knowledge (2003) 36, 44 (stressing indeterminacy in the economic analysis of TRIPS-related issues owing to lack of objective data). 
There is, for example, no expert body of legal and economic scholars charged with disinterested analysis of these issues, or with the collection of systematic inputs from all affected interests. The one agency entrusted with managing intellectual property rights at the international level - the World Intellectual Property Organization (WIPO) - has recently interpreted its legislative mandate as one of progressively elevating intellectual property rights throughout the world. Whether this strategy actually benefits innovation or the world's inhabitants seems to count for little in implementing this mandate. ${ }^{54}$

Even if this 'democratic deficit' were overcome, differences of resources, institutional capabilities, and organization could still combine to create both a knowledge gap and a power gap at the regulatory center owing to the inexperience and ineffectiveness of the developing countries as a whole to manage their interests in this sector. Most of these states do not yet treat intellectual property as an integral part of national or regional systems of innovation. They are compliance oriented, not given to interagency review of the issues, but rather prone to leaving them to their Intellectual Property bureaus and to bartering concessions in this area for advantages in other areas, without any solid basis for calculating the true costs and benefits of these tradeoffs. ${ }^{55}$

Most developing countries lack access to impartial technical assistance, and must rely instead on assistance funded by sources whose interests are not necessarily in line with theirs. ${ }^{56}$ They are also advised by nongovernmental organizations (NGOs), which have managed to produce an impressive array of public-oriented outcomes in an increasing number of forums. ${ }^{57}$ Yet, good as they sometimes are in tactical maneuvers on well-defined issues, such as public health, the NGOs' contribution cannot compensate for the general inability of the developing countries to integrate multilateral negotiations into broader national and regional innovation strategies. ${ }^{58}$

Those few developing countries that have built some capacity to participate in standard-setting exercises may run into coercive pressures from govern-

54 See e.g., Carlos Correa, 'Formulating Effective Pro-development National Intellectual Property Policies', in Trading in Knowledge, above n 53 at 209, 214 (criticizing WIPO Secretariat for emphasizing 'the benefits and largely ignoring the costs of IPR protection' and generally failing 'to present the range of options available to developing countries'). See generally Sisule F. Musungu and Graham Dutfield, Multilateral Agreements and a TRIPS-plus World: The World Intellectual Property Organization (WIPO), Quaker U.N. Office, Geneva, TRIPS Issues papers No. 3 (2003).

55 See e.g., Correa, above n 54. For the situation prior to 1994, see J. Watal above n 4.

56 See Musungu and Dutfield, above n 54; papers presented at UNCTAD/ICTSD Second Bellagio Meeting on Intellectual Property and Development, UNCTAD/ICTSD, 17-20, September 2003.

57 See Laurence R. Helfer, 'Regime Shifting: The TRIPS Agreement and New Dynamics of International Intellectual Property Lawmaking', 29 Yale J. Int'l L. 1 (forthcoming 2004).

58 Cf. John Barton, 'Integrating IPR Policies in Development Strategies', in Trading in Knowledge, above $\mathrm{n} 53$ at $57,60-64$. 
ments and corporations whose interests they challenge. Increasingly, such pressures are exerted in bilateral, unequal bargaining situations in which everhigher IPRs are demanded without regard to the legal or political consequences of undermining the basic MFN principles of the GATT itself. ${ }^{59}$

In effect, this regulatory gap at the center is left at the mercy of powerful state actors representing the interests of corporate clients at the international level. These clients, which may constitute a de facto 'knowledge cartel', 60 control the distribution of a disproportionately large share of existing technologies without necessarily being particularly innovative themselves. Their membership typically does not include the small- and medium-size entrepreneurs, who drive innovation in the United States, nor does it include the universities and public research institutes who depend on constant access to facts, data, discoveries, and the research results of others.

Because the members of this knowledge cartel depend on sales of existing innovation, they push their governments to regulate the global market in ways that lock in temporary competitive advantages without necessarily advancing the global public interest in innovation, competition, or the provision of complementary public goods. Indeed, representatives of the global public interest are unlikely to be seated at the table where hard-law negotiations take place. ${ }^{61}$ Without a legitimizing governance process that adequately represents all stakeholders, the baseline need to support both public and private interests in the transnational market for knowledge goods thus risks being compromised in at least two ways.

First, there is a pronounced risk that a substantial component of the recently liberated global trade market will become re-regulated through IPRs to reflect dubious practices in developed markets for knowledge goods that may actually hamper both innovation and competition in the long run. Second, there is the further risk that an over-regulated market for knowledge goods could compromise the ability of nation states to supply other public goods that only they can provide in a decentralized world economy.

\section{Instability and loss of balance in developed intellectual property regimes}

The drive to stamp out free-riding practices thus tends to obscure serious problems engendered by the radical transformation of IP policies that has occurred in developed countries. This transformation constitutes a prolonged effort to strengthen the protection of investors in cutting-edge technologies,

59 See Frederick M. Abbott, Trade Diplomacy, the Rule of Law and the Problem of Asymmetric Risks in TRIPS, Quaker United Nation Office Occasional Paper 13 (September 2003), available at http:// www.geneva.quno.info/pdf/OP13 Abbottfindft rev_1.pdf (visited 1 May 2003); Drahos, above n 5.

60 'The difficulty of entry into markets dominated by multinational oligopolies is thus compounded by the international IP system.' Barton, above n 58, at 61. See generally, Hanns Ullrich, above n 45.

61 See Helfer, above n 57 (distinguishing hard and soft law processes). 
especially computer programs and biogenetically engineered products, which fit imperfectly within the classical patent and copyright paradigms. ${ }^{62}$

Under the classical IP system, as implemented in the United States through the mid-1960s, for example, the strong legal monopolies of the patent law protected only a narrow layer of discontinuous inventions that fell outside the technical trajectories guiding the day-to-day application of normal scientific discoveries. ${ }^{63}$ Entrepreneurs constrained to innovate in a highly competitive economy looked to the liability rules of unfair competition law, especially trade secret law, to provide natural lead time in which to recoup their investments, and to the rules of trademark law to maintain a foothold in the market based on their reputations as producers of quality goods. ${ }^{64}$ Because copyright law excluded industrial products in virtually every form, ${ }^{65}$ their producers could not hope to avoid the rigors of competition by masquerading as authors of literary and artistic works. As for the rest, vigorously enforced antitrust laws, supplemented by a robust doctrine of patent misuse, rid the market of deleterious patent pools and other barriers to entry and, in the view of Professors Mowery and Rosenberg, by disciplining Bell Labs and IBM, paved the way for the technological leaps of the 1970s and 1980s. ${ }^{66}$

This classical system of intellectual property protection obliged innovators to look to the public domain for the basic inputs of most technological development. They took the availability of vast amounts of governmentgenerated or government-funded scientific data and technical information for granted; and they assumed that facts and data generated by non-confidential public research endeavors at universities and other nonprofit institutions would become public goods available to all. ${ }^{67}$ Investors also assumed that sub-patentable innovations could be reverse-engineered by proper means that would endow competitors with improvements and lower cost modes of production. They further assumed that even patented inventions would enter

62 See generally J. H. Reichman, 'Legal Hybrids between the Patent and Copyright Paradigms', 94 Colum. L. Rev. (1994) 2432; J. H. Reichman, 'Charting the Collapse of the Patent-Copyright Dichotomy', 13 Cardozo Arts \& Ent. L. J. (1995) 475; see also James Boyle, Shamans, Software, and Spleens, above n 48, at 119-44; Pamela Samuelson et al., 'A Manifesto Concerning the Legal Protection of Computer Programs', 94 Colum. L. Rev. (1994) 2308.

63 See e.g., R. Nelson and R. Merges, 'On the Complex Economics of Patent Scope', 90 Colum. L. Rev. (1990) 839.

64 P. Samuelson and S. Scotchmer, 'The Law and Economics of Reverse Engineering', 111 Yale L. J. (2003) 157.

65 Baker v Selden, 101 U.S. 99 (1879); Sears, Roebuck E Co. v Stiffel Co., 376 U.S. 225 (1964); Compco Corp. v Day-Brite Lighting, Inc., 376 U.S. 234 (1964).

${ }^{66}$ David S. Mowery and Nathan Rosenberg, 'The U.S. National Innovation System', in Richard R. Nelson (ed), National Innovation Systems (1993) 29-75.

67 Reichman and Uhlir, above n 28 (citing authorities); see also Rebecca Eisenberg, 'Proprietary Rights and the Norms of Science in Biotechnology Research', in P. E. Stephan and D. B. Audretsch (eds), The Economics of Science and Innovation (The International Library of Critical Writings in Economics, 117:1) (2000) 357-411 (originally published under the same title in 97 Yale L.J. (1987) 177). 
the public domain at fairly short intervals and that it was not inordinately difficult to work around these inventions if the commercial payoffs justified the effort. However, basic underlying scientific discoveries would remain freely available.

If we now fast forward to a descriptive analysis of the current US system, one could hardly imagine a starker contrast. The United States Court of Appeals for the Federal Circuit, entrusted by Congress to manage the patent system, has deliberately remolded that system to protect investment as such, rather than discontinuous technical achievements that elevate the level of competition. The patent system has accordingly degenerated to protecting incremental slivers of know-how applied to industry, including those very business methods that were formerly the building blocks of the free-enterprise economy. ${ }^{68}$

The copyright system, expanding in the same direction, now confers virtually perpetual protection on computer software and digital productions of all kinds, and it encourages creators to surround even their unprotectable technical ideas and components with untouchable electronic fences. ${ }^{69}$ Once surrounded by these fences, even the underlying facts and data may be put off limits; while one-sided electronic adhesion contracts may override public interest exceptions favoring education and public research, and they may even prohibit reverse engineering by honest means. ${ }^{70}$

As hybrid IP regimes multiply to fill still other perceived gaps in the system, there are virtually no products sold on the general products market that do not come freighted with a bewildering and overlapping array of exclusive property rights that discourage follow-on applications of routine technical know-how. ${ }^{71}$ Weak enforcement of antitrust laws then further reinforces the barriers to entry erected upon this thicket of rights, while the need to stimulate and coordinate investment in complex innovation projects justifies patent pools, concentrations of research efforts, and predatory practices formerly thought to constitute misuses of the patent monopoly. ${ }^{72}$

68 State Street Bank \& Trust Co. v Signature Financial Group, Inc., 149 F.3d 1368 (Fed Cir. 1998); Reichman, 'Saving the Patent System from Itself', above n 49.

69 Digital Millennium Copyright Act of 1998, 17 U.S.C. $\S \S 201-1205$ [hereinafter DMCA]; Pamela Samuelson, 'Mapping the Digital Public Domain: Threats and Opportunities', 66 Law \& Contemp. Probs. (2003) 147.

70 Bowers v Baystate Techs., 320 F.3d 1317 (Fed. Cir. 2003); J. H. Reichman and Jonathan Franklin, 'Privately Legislated Intellectual Property Rights: Reconciling Freedom of Contract with Public Good Uses of Information', 147 U. Pa. L. Rev. (1999) 875; Nina Elkin-Koren, 'A Public-Regarding Approach to Contracting Over Copyrights', in Expanding the Boundaries of IP, above n 41, at 191; Jane C. Ginsburg, 'U.S. Initiatives to Protect Works of Low Authorship', in Expanding the Boundaries, above n 41, at 55.

${ }^{71}$ See J. H. Reichman, 'Of Green Tulips and Legal Kudzu; Repackaging Rights in Subpatentable Innovation', 53 Vand. L. Rev. (2000) 1743.

72 See e.g., Ullrich, above n 45. 
The end results of this process, which James Boyle has felicitously called the 'Second Enclosure Movement', ${ }^{73}$ are not fully known, but the problems it is already causing for developed systems of innovation shed light on the larger problems facing the international economy. The availability of upstream data and scientific information from the public domain is shrinking at the very moment when advances in Internet technologies make it possible to link both centrally located and distributed data repositories as never before. A growing thicket of rights surrounds gene fragments, research tools, and other upstream inputs of scientific research, and the resulting transaction costs impede and delay research and development undertaken in both the public and private sectors. ${ }^{74}$ Lost research and competitive opportunities appear to be mushrooming as exchanges of even government-funded research results become problematic. ${ }^{75}$ As well-known economists point out, complex research and development projects at every level - whether public or private - will become increasingly impracticable if too many owners of too many rights have to be tithed along the way. ${ }^{76}$

Meanwhile, the sharing norms of science and the principle of open access to data have begun to break down as universities commercialize publicly funded research products. New intellectual property rights in collections of data adopted in the EU and pending adoption in the $\mathrm{US}^{77}$ - further undermine these norms by enabling scientists, universities, and entrepreneurs to retain control of data and technical information even after the publication of research results in articles or after public disclosure for purposes of filing patent applications on such results. ${ }^{78}$

73 Boyle, 'Second Enclosure Movement', above n 50. See generally 'Duke Symposium on Intellectual Property Rights and the Public Domain', 66 Law \& Contem. Probs (2003) 1-462.

${ }^{74}$ See e.g., Michael A. Heller and Rebecca S. Eisenberg, 'Can Patents Deter Innovation? The Anticommons in Biomedical Research', 280 Science (1998) 698; Arti Kaur Rai, above n 41; Rebecca S. Eisenberg, 'Bargaining over the Transfer of Proprietary Research Tools', in Expanding the Boundaries of IP, above n 41; see also Walter W. Powell, 'Networks of Learning in Biotechnology: Opportunities and Constraints Associated with Relational Contracting in a Knowledge-Intensive Field', in Expanding the Boundaries of IP, above n 41 at 251.

75 See Reichman and Uhlir, above n 28.

76 See e.g., Richard Nelson, 'The Market Economy and the Scientific Commons', in International Public Goods and Intellectual Property, above n 29; Paul A. David, 'A Tragedy of the Public Knowledge "Commons"? Global Science, Intellectual Property and the Digital Technology Boomerang', SIEPR Discussion Paper no. 00-02, Stanford Institute for Economic Policy Research (2000), available at http://siepr.stanford.edu/papers/pdf/00-02.html (last visited 8 January 2004); Paul David and Michael Spence, 'Towards Institutional Infrastructures for E-Science: The Scope of the Challenge', Oxford Internet Institute (14 September 2002).

77 Directive 96/9/EC of the European Parliament and of the Council on the legal protection of databases, O.J. L 77/20, 27 March 1996 [hereinafter E.C. Database Directive]; H.R. 3261, 108th Cong., 1st Sess. (2003); see generally J. H. Reichman, 'Database Protection in a Global Economy', above $\mathrm{n} 41$.

78 See e.g., Reichman and Uhlir, above n 28; The Royal Society, 'Keeping Science Open: The Effects of Intellectual Property Policy on the Conduct of Science' Policy doc. 02/03 (April 2003) [hereinafter Royal Society Report]. 
These and other social disutilities cast light on the problems afflicting the international system and raise serious questions about its future prospects. They represent the unintended consequences of an excess of regulation and interference with market forces. In allowing large multinational firms to lock in temporary advantages, ${ }^{79}$ the IP system could discourage innovation by those same small and medium-sized firms that depend on access to public domain inputs for developing applications of new technologies.

In this environment, economists fear that the ratcheting up of intellectual property standards will boomerang against the capacity to innovate in developed countries. ${ }^{80}$ They ask whether the breakthrough inventions of the recent past would still be possible in a protectionist environment and in the presence of a shrinking public domain. ${ }^{81}$ They make us question whether future innovation will flourish in a dynamic, transnational system of innovation liberated from excessive governmental regulation or flounder in a re-regulated, ever more anti-competitive market that increasingly resembles the top-down economies that trailed behind US high-tech industries in the past.

\section{Exporting a dysfunctional system to the rest of the world?}

Logically, the shift to a high-protectionist agenda in the developed countries should spark a cautious and skeptical response from the rest of the world for a number of reasons. First, the TRIPS Agreement itself, coupled with the WIPO Copyright Treaties of $1996,{ }^{82}$ foreshadowed a revolutionary transformation of the legal and economic infrastructures in developing countries, and they need a lengthy period of time in which to digest and adjust to these reforms. These countries can hardly absorb the unknown social costs of new intellectual property burdens when the real costs of the last round of legislative initiatives are still making themselves felt. ${ }^{83}$ Yet, this reality has not attenuated the pressures for TRIPS-plus standards in both multilateral and bilateral forums.

A second reason for diffidence in developing countries is the scholarly debate that the high-protectionist agenda has generated in both the United States and Europe, and the corresponding fears that this agenda could harm investment and research-based innovation in the long run. If the critics prove

79 See e.g., Peter Drahos and John Braithwaite, Information Feudalism (2002); Susan K. Sell, Power and Ideas: North-South Policies of Intellectual Property and Antitrust (1998); Susan K. Sell, Private Power, Public Law: The Globalization of Intellectual Property Rights (2003).

${ }^{80}$ See above n 76 and accompanying text. Professor David speaks explicitly of a 'boomerang' effect. See Paul A. David, 'A Tragedy of the Public Knowledge "Commons”?, Global Science, Intellectual Property and the Digital Technology Boomerang', above n 76 .

81 See above nn 73-76; Graeme B. Dinwoodie and Rochelle Cooper Dreyfuss, 'International Intellectual Property Law and the Public Domain of Science' [this symposium].

82 See above nn 3, 6.

83 See CIPR, above n 10, at 155-157. 
right, then the last thing the developing countries should want to do is to emulate these policies.

Consider, for example, that the drive to further harmonize the international minimum standards of patent protection at $\mathrm{WIPO}^{84}$ has occurred at the very time when the domestic standards of the United States and the operations of its patent system are under critical assault. That country's patent system has been subject to scathing criticism in numerous law journal articles, ${ }^{85}$ in the scientific literature, ${ }^{86}$ and even in magazines of general circulation. ${ }^{87}$ New proposals to reform both the domestic and international patent systems appear frequently, and commissions to study or propose reform are operating on numerous fronts. ${ }^{88}$ How, under such circumstances, could it be timely to harmonize and elevate international standards of patent protection - even if that were demonstrably beneficial - when there is so little agreement in the US itself on how to rectify a dysfunctional apparatus that often seems out of control?

Even in the courts themselves, which, in the United States, still operate at some degree of removal from lobbying and other political pressures, there are elements of change, uncertainty, and disarray that do not bode well for an international standard-setting exercise. In the past few years, for example, the US federal courts have significantly changed the way patent claims are interpreted; narrowed the doctrine of equivalents in patent infringement actions; practically eliminated the research exemption under which universities had operated for 50 years or more; expanded patent protection of computer programs in ways that both the domestic and European authorities

84 WIPO Draft Patent Treaty, above n 7.

85 See e.g., Arti K. Rai, 'Engaging Facts and Policy: A Multi-Institutional Approach to Patent System Reform', 103 Colum. L. Rev. (2003) 1035; Jay P. Kesan, 'The Private and Social Costs of the Patent System: Why Bad Patents Survive in the Market and How We Should Change', working paper (2004) (citing articles by Thomas, Leung, Quillen and Ogden, Baird and others); Jay P. Kesan, 'Carrots and Sticks to Create a Better Patent System', 17 Berkeley Tech. L. J. (2002) 763; Robert Merges, 'As Many as Six Impossible Patents before Breakfast: Property Rights for Business Concepts and Patent System Reform', 14 Berkeley Tech. L. J. (1999) 577; John Allison and Mark Lemley, 'The Growing Complexity of the United States Patent System', 82 Boston U. L. Rev. (2002) 77.

86 See e.g., Heller and Eisenberg, above n 74; John K. Barton, 'Reforming the Patent System', 287 Science (2000) 1933; see also Eisenberg, 'Bargaining over the Transfer of Proprietary Research Tools', above n 41; John P. Walsh, Ashish Arora, and Wesley M. Cohen, 'Effects of Research Tool Patents and Licensing on Biomedical Innovation', in W.M. Cohen and S.A. Merrill (eds), National Research Council, Patents in the Knowledge-Based Economy (2001) 285-340.

87 James Gleick, 'Patently Absurd', New York Times Magazine (12 March 2000), at 44.

88 See e.g., John K. Barton, above n 86; Rai, above n 85; Paul Edward Geller, 'An International Patent Utopia?', 25 E.I.P.R. (2003) 515. At the time of writing, both the Federal Trade Commission and the National Research Council were conducting studies of the U.S. patent system with a view to launching reform proposals. See also Mark A. Lemley, 'Rational Ignorance at the Patent Office', 95 Northwestern U. L. Rev. (2001) 1 (finding that poor patent examination procedures save resources because few patents are actually litigated or licensed). Taken to their logical conclusion, Prof. Lemley's findings would ironically suggest that an efficient worldwide patent regime should revert to the registration system previously used in France and Italy and not the examination system derived from US and German practice. 
had previously opposed; and opened patent law to the protection of business methods in ways that have disrupted settled commercial activities. ${ }^{89}$

These events should make US authorities cautious about surrendering the power to undertake adjustments in the future, and policymakers in the rest of the world should become wary of locking themselves into the untested results of ad hoc judicial tinkering in a single country. ${ }^{90}$ It is therefore disconcerting to think of 'harmonizing' the international patent system at such a time, when the risks of unintended harm to worldwide competition seem high, and when the only basis for a consensus on harmonization might be to squeeze out the remaining flexibilities in the TRIPS Agreement.

One can paint a similar picture with respect to copyright and related rights laws. Here, the developing countries, acting in concert with user interests in the developed countries, managed to ensure that the 1996 WIPO treaties governing works transmitted in digital media continued to allow certain privileged uses and exceptions permitted by prior law. ${ }^{91}$ Notwithstanding this outcome at the international level, the United States and the European Union both ignored these provisions and cut well back on permitted uses in their domestic implementation laws; ${ }^{92}$ and they have been pressing developing countries for still higher standards of protection in bilateral negotiations.

Yet, these domestic initiatives to expand and strengthen copyright protection of works transmitted over digital telecommunications networks have generated popular resistance to copyright norms in the United States as well as strenuous academic concerns about free competition, free speech, privacy, and the need to ensure access to inputs for future creative works. ${ }^{93}$

${ }^{89}$ Markman v Westerview Instruments, Inc., 52 F. 3rd 967 (Fed. Cir. 1995), aff’d, 917 U.S. 370 (1996); Festo Corp. v Shoketsu Kinzoku Kogyo Kabushiki Co., 234 F. 3d 558 (Fed. Cir. 2000), reversed 535 S. Ct. 2519 (2001); Duke v Madey, 307 F.3d 1351 (Fed. Cir. 2002); In re Alappat, 33 F. 3rd 1526 (1994); State Street Bank \& Trust Co. v Signature Financial Group, Inc., 149 F.3d 1368 (Fed Cir. 1998). See generally Gerald Sobel, 'Competition Policy in Patent Cases and Antitrust', in Perspectives on Properties of the Human Genome Project, above n 49, at 23, 26-41 ('The Federal Circuit's transformation of the law').

90 Cf. e.g., Ruth L. Okediji, 'Public Welfare and the Role of the WTO: Reconsidering the TRIPS Agreement', 17 Emory Int'l L. Rev. (2003) 821, 822-25; G. B. Dinwoodie and R. C. Dreyfuss, above $\mathrm{n} 81$.

91 See e.g., WIPO Copyright Treaty, above n 6, arts. 8, 10; Agreed Statements Concerning the WIPO Copyright Treaty, Concerning Article 10, adopted by the Diplomatic Conference on 20 December 1996, WIPO Doc. CRNR/DC/96 (23 December 1996); Samuelson, The U.S. Digital Agenda at WIPO, above n 6; Ruth Okediji, Development in the Information Age: Issues in the Regulation of Intellectual Property Rights, Computer Software and Electronic Commerce, UNCTAD/ICTSD (2003).

92 DMCA, above n 69; Directive 2001/29/EC of the European Parliament and of the Council on the harmonization of certain aspects of copyright and related rights in the information society, O.J. L 167/10, 22 May 2001; see generally Jessica Litman, Digital Copyright: Protecting Intellectual Property on the Internet (2001).

93 See e.g., Yochai Benkler, 'Through the Looking Glass: Alice and the Constitutional Foundations of the Public Domain', 66 L. \& Contemp. Probs. (2003) 173; P. Samuelson, 'Mapping the Digital Public Domain', above n 69. See generally National Research Council, The Digital Dilemma: Intellectual Property in the Information Age (2000). 
Further harmonization efforts in this climate thus amount to a gamble from which bad decisions and bad laws are far more likely to emerge than good laws that appropriately balance public and private interests.

There are still other risks of participating in further harmonization exercises that are even more sobering. First, certain new initiatives - such as the European database protection right ${ }^{94}$ - could radically subvert the classical intellectual property tradition built around patents and copyrights, with unintended consequences that could elevate the costs of research and development across the entire knowledge economy. While pressures to adopt similar legislation in the United States mount, legal and economic analysis of database protection as a generator of anti-competitive effects and of potential obstacles to innovation also grow more refined and alarming. ${ }^{95}$ Such premature initiatives could undermine sound economic development everywhere, and action in this regard at the international level would require great caution under the best of circumstances. ${ }^{96}$

In this climate, it is difficult to see that developing countries have anything to gain from new efforts to strengthen IP standards. As matters stand, these international standard-setting exercises are not being conducted either to promote their interests or the global public interest. On the contrary, the developing countries play virtually no role in norm formation (partly due to their disorganized institutional apparatus), ${ }^{97}$ and the global public interest is hardly represented at the negotiating tables in the developed countries themselves, much less in international forums where hard law is enacted. ${ }^{98}$ From this perspective, even if the developing countries possessed more bargaining power than they do, they should remain wary of further harmonization exercises in the absence of effective strategies for preserving and enhancing the public good side of the equation. Until this gap in international lawmaking has been suitably addressed, such initiatives will continue to suffer from a basic design defect.

Any gains in efficiency of operations and lower transaction costs that greater harmonization might entail are likely to be offset by losses of sovereign power to control the single states' own innovation policies; by a shrinking public

94 E.C. Database Directive, above n 77.

95 See e.g., Paul David, above n 53; Royal Society Report, above n 78. See also Jacqueline Lipton, 'Balancing Private Rights and Public Policies: Reconceptualizing Property in Databases', 18 Berkeley Tech. L. J. 773 (2003).

96 See Reichman, 'Database Protection in a Global Economy', above n 41 (proposing minimalist interim agreement to avoid wholesale duplication of noncopyrightable collections of data). Equally problematic as a candidate for 'harmonization' is competition law, which still affords a potential range of checks and balances on legal monopolies and restrictive licensing agreements. See Hanns Ullrich, above n 45 [this symposium]; Eleanor Fox, 'Can Antitrust Policies Protect the Global Commons from the Excesses of IPRs?', in International Public Goods and Intellectual Property, above $\mathrm{n}$ 29.

97 See below text accompanying nn 153-57.

98 See generally Helfer, above n 57. 
domain; by still higher costs of technological inputs and reverse engineering; and by growing thickets of rights that will make transfer of technology harder for those operating outside patent and IP pools (pools that could soon include major research universities as well as corporate holding companies). With every rise in international IP standards, moreover, there will likely be a corresponding loss of flexibility under the TRIPS Agreement and still greater risks deriving from the possible claims of nonviolatory acts of nullification that new standards may engender in the future. ${ }^{99}$

\section{B. Impact of intellectual property standards on the reserved welfare powers of WTO Members}

An International Task Force on Global Public Goods was recently created at the initiative of France and Sweden to explore further the concept of GPG, to clarify the definition, and to propose concrete and operational recommendations to policymakers. In assessing how such goods could collectively be harnessed to reduce poverty and enhance welfare, this group has given priority to 'peace and security; trade regimes; financial stability; control of communicable diseases; and sustainable management of the national commons'. ${ }^{100}$ A sixth item, 'knowledge', is also included in the list for its 'classical public good properties'. However, the task force believes that this rubric requires a separate and particular treatment owing to its 'cross-cutting' nature and to the ever-increasing role of knowledge as both a private and public good. ${ }^{101}$

As programs like this one emerge to focus attention on the role of GPG in advancing the welfare of developing countries, they increasingly encounter obstacles and problems stemming from the existence of patents and other IPRs held by universities, research institutes, and the private sector on fundamental research technologies. ${ }^{102}$ These intellectual property rights may play a positive role, especially when they enable private investors to take publicly funded research results out of the laboratory and into the stream of commerce. ${ }^{103}$ Increasingly, however, these rights have invaded the research commons itself and made it both costly and difficult to obtain cutting-edge

\footnotetext{
99 See TRIPS Agreement, above n 3, art. 64.2, 64.3.

100 See International Task Force on Global Public Goods, Report of the First Meeting, 25-26 September 2003, available at http://www.gpgtaskforce.org/bazment.aspx?timestamp= 632012250271530272\&page_id=142\#bazAnchor_ (visited 12/21/2003).

101 Id; see below text accompanying nn 159-76.

102 John Barton, 'Integrating IPR Policies in Development Strategies', above n 58, at 61.

103 See e.g., Rebecca S. Eisenberg, 'Public Research and Private Development: Patents and Technology Transfer in Government-Sponsored Research', 82 Va. L. Rev. (1996) 1663.
} 
technologies needed for public health, agriculture, environmental protection, and the provision of other public goods. ${ }^{104}$

Private capture of the global regulatory process for IP standard setting not only undermines the ability of governments in developing countries to devise and promote their own national systems of innovation. It also erodes national control over the provision of non-TRIPS public goods by other affected ministries that lack inputs into the intellectual property standard-setting exercises.

The risks of progressively entangling the WTO Members' police and welfare powers in the coils of IP treaties are aggravated by the poor organizational capacities of developing countries and their lack of expertise, which have so far impeded recourse to public-interest tools that the TRIPS Agreement still makes available. ${ }^{105}$ They are further aggravated by the practice of excluding those who disagree with the knowledge cartel from key negotiating forums and from a disinclination to include those who speak for the public interest or the preservation of complementary public goods in 'technical' standard-setting exercises.

The stakeholders excluded from the process of norm building in the field of IPRs have not quietly faded away, but have, on the contrary, worked through numerous NGOs to defend global public goods against further encroachment in parallel or alternative forums. This strategy of 'regime shifting' ${ }^{106}$ imitates that of the knowledge cartel, which in the 1990s shifted the regulation of IPRs from WIPO, whose secretariat at that time was overtly sympathetic to the goals of developing countries, to the GATT (later to become the World Trade Organization), where market power was the prevailing influence.

As Professor Laurence Helfer shows, these parallel efforts to balance the private interests of intellectual property rights holders against larger public interest goals have been increasingly successful with respect to public health, biodiversity, plant genetic resources, human rights, and the protection of traditional knowledge and culture. ${ }^{107}$ The most dramatic success came in the

104 See e.g., Boyle, 'Enclosing the Genome', above n 49; Carlos M. Correa, 'Internationalization of the Patent System and New Technologies', above n 22, at 545-48; Robert Evenson, 'Agricultural Research and Intellectual Property Rights', in International Public Goods and Intellectual Property, above n 29; Arti K. Rai and Rebecca S. Eisenberg, 'Bayh-Dole Reform and the Progress of Biomedicine', 66 Law \& Contemp. Probs. (2003) 289.

105 For a major exception, see Decision of the South African Competition Commission concerning AIDS medicines, available at www.cptech.org/ip/health/sa/settlement12092003.pdf (visited 7 February 2004). See generally J. H. Reichman with Catherine Hasenzahl, Non-voluntary Licensing of Patented Inventions; The Law and Practice of the United States, UNCTAD/ICTSD (2003) (discussing broad reliance on government use provisions in US law).

106 Helfer, above n 57.

107 'Increasingly broad and vocal consortiums of ... NGOs ... are challenging the "moral, political and economic legitimacy" of TRIPS, focusing on provisions of the treaty that affect public health, human rights, biodiversity, and plant genetic resources.' Helfer, above n 57, at 3-4. See e.g., Convention on Biological Diversity (CBD), done at Rio de Janeiro, 5 June 1997, 31 I.L.M. 818 (1993); International Treaty on Plant Genetic Resources for Food and Agriculture (ITPGR), opened for signature 3 November 2001 (not yet entered into force); Helfer, above n 57, at 26-51. 
area of public health, where the NGOs' campaign for access to essential medicines culminated in the Ministerial Declaration on TRIPS and Public Health, and in the supplementary decision of 30 August 2003. ${ }^{108}$ Also noteworthy from this perspective is the work of NGOs within United Nations human rights bodies, which 'has led to the adoption of non-binding declarations and interpretive statements that emphasize the public's interest in access to new knowledge and innovations and assert that states must give primacy to human rights where the two sets of obligations conflict'. ${ }^{109}$

Professor Helfer identifies at least four different goals that NGOs have striven to fulfill in these parallel regime-shifting initiatives. First, they seek to promote and maximize desired policy outcomes that differ from those of IP stakeholders, particularly where those policy outcomes 'have been ignored or marginalized in other international regimes'. ${ }^{110}$ Second, they have created safety valves that help to relieve pressure for action at the WTO by 'consigning an issue area to a venue where consequential outcomes and meaningful rule development are unlikely to occur'. ${ }^{11}$ Third, regime shifting focuses efforts on generating norms that operate to check or counter the goals of the high-protectionist coalitions and thereby provide governments 'a "safe space" in which to analyze and critique those aspects of TRIPS ... they find ... problematic'. ${ }^{112}$ Fourth, NGO activities seek to blend or integrate new hard and soft law rules into both WTO and WIPO processes as a means of focusing attention on other public goods besides innovation, and of enabling 'developing countries to achieve outcomes not attainable' in any single negotiating forum. ${ }^{113}$

There are, of course, risks of overkill and unintended consequences inherent in these regime-shifting exercises. Putting human rights behind the

108 WTO Doha Ministerial Conference, Declaration on the TRIPS Agreement and Public Health, WT/ MIN(01)/DEC/W/2 (14 November 2001) [hereinafter Doha Declaration on TRIPS and Public Health], plus Decision of General Council of 30 August 2003, Implementation of paragraph 6 of the Doha Declaration on the TRIPS Agreement and Public Health, WT/L/540 (1 September 2003). See generally, Frederick M. Abbott, 'The Doha Declaration on the TRIPS Agreement and Public Health: Lighting a Dark Corner at the WTO', 5 JIEL (2002) 469; Duncan Matthews, 'WTO Decision on Implementation of Paragraph 6 of the Doha Declaration on the TRIPS Agreement and Public Health: A Solution to the Access to Essential Medicines Problem?', 7(1) JIEL (2004) 73.

109 Helfer, above n 57, at 46 (citing authorities); see generally id, at 48-51; Audrey R. Chapman, 'The Human Rights Implications of Intellectual Property Protection', 5 JIEL (2002) 861, 867 (stating that 'from a human rights perspective, intellectual property protection is understood more as a social product with a social function, and not primarily as an economic relationship').

${ }^{110}$ Helfer, above n 57, at 55. 'By attending meetings, submitting documents to expert and working groups, and interacting with government officials ... [in the biodiversity, PGR, public health, and human rights regimes,] NGOs can shape debates over principles, norms, and rules in ways that are foreclosed to them within more state-centric regimes.' Id, at 55.

111 Helfer, above n 57, at 56. This may serve the interests of both developing and developed countries in different ways. See id, at 54-55.

$112 \mathrm{Id}$, at 58.

113 Helfer, above n 57, at 59-62. Cf. also Boyle, 'Enclosing the Genome', above n 49 (stressing deeper moral and philosophical dimensions of this focus). 
drive for access to essential medicines clearly strengthened the claims of those dying from AIDS while governments debated the intricacies of patent law and the effects of reference pricing on the cost of medicines in developed countries. ${ }^{114}$ It has done little to clarify the complex problems of funding risky research and development that lie at the heart of the patent system, ${ }^{115}$ although new NGO initiatives that focus specifically on devising alternative research and development strategies may yield more promising results in the future. ${ }^{116}$

Similarly, while the drive for legal protection of traditional knowledge under some form of intellectual property right could give poor countries a bigger stake in the global market for knowledge goods, ${ }^{117}$ it could further privatize resources - especially genetic resources - that were previously treated as agricultural public goods. It could also make innovation and creativity more difficult in the very countries that are the richest suppliers of traditional knowledge, especially if foreign firms that acquired these inputs subject to 'benefit sharing' royalty agreements were under no effective ancillary obligations to share their technological know-how with the countries of origin. ${ }^{18}$ Above all, legal protection of traditional knowledge could boomerang against developing countries as a group if they were tempted to trade it for a strong database protection treaty, as the European Union proposes. ${ }^{119}$

In any event, the burgeoning encroachment of international IPRs on the reserved welfare and police powers of states constitutes an anomaly in public international law that must be fixed before it cripples the WTO and fatally

114 See e.g., Patricia Danzon and Adrian Towse, 'Differential Prices for Pharmaceuticals: Reconciling Access, R\&D, and Patents', in International Public Goods and Intellectual Property, above n 29.

115 See e.g., Alan O. Sykes, 'TRIPs, Pharmaceuticals, Developing Countries and the Doha "Solution", 3 Chi. J. Int'l L. (2002) 47.

116 See Henry Grabowski, 'Patents, Innovation and Access to New Pharmaceuticals', in International Public Goods and Intellectual Property, above n 29; James Love and Tim Hubbard, 'From TRIPS to RIPS: A Better Trade Framework to Support Innovation in Medical Technologies', paper presented at the workshop on economic issues related to access to HIV/AIDS care in developing countries, Agence Nationale de Recherches sur le Sida, Marseille, France (2003), available at http:// www.cptech.org/ip/health/rndtf/trips2rips.pdf (visited 30 January 2004).

117 See Thomas Cottier and Marion Panizzon, 'Legal Perspectives on Traditional Knowledge: The Case for Intellectual Property Protection', in International Public Goods and Intellectual Property, above $\mathrm{n} 29$.

118 See e.g., Gustavo Ghidini, 'Equitable Sharing of Benefits under the Biodiversity Convention', in International Public Goods and Intellectual Property, above n 29.

119 That solution could limit the ability of researchers and entrepreneurs in developing countries to access scientific and technical data and information - the most important input into the knowledgebased economy - at the very moment when digitized network technologies could make such data available as never before. It could also elevate the costs of innovation everywhere while creating global barriers to entry in favor of a handful of firms that hold disproportionate market power in the supply of information as such. See e.g., Reichman and Uhlir, above n 28; Reichman, 'Database Protection in a Global Economy', above n 41. 
weakens the infrastructure that supports world trade. One should not view this as some minor irritant to be blamed on NGOs or recalcitrant developing countries. Telling poor people in rich countries that the TRIPS Agreement prevents domestic policymakers from regulating access to essential medicines will not long remain politically feasible. As matters stand, if nothing had been done to address the plight of millions dying of AIDS because of TRIPS patent rights, then the WTO would have contributed to the greatest health tragedy in history. ${ }^{120}$

Similar errors must be prevented in other critical areas. Until there are some agreed global governance mechanisms for food security, agriculture, human rights, public health, environmental protection, scientific research, and other public goods, states cannot be presumed to have surrendered sovereign police and welfare powers in the course of intellectual property standard-setting exercises at which their ministries of health, education, agriculture, and public welfare played little or no role.

Professor Robert Howse has suggested that WTO dispute-settlement panels in cases covered by the TRIPS Agreement could attenuate such conflicts by invoking article 8.1 of that Agreement. ${ }^{121}$ This provision recognizes the power of states 'in formulating or amending their laws and regulations, [to] adopt measures necessary to protect public health and nutrition, and to promote the public interest in sectors of vital importance to their socio-economic and technological development ... [if] consistent with the provisions of this Agreement'. ${ }^{122}$ It could allow panels to interpret TRIPS provisions in the light of other relevant international laws, including "soft law" sources, such as resolutions and authoritative reports and policy statements of relevant international forums'. ${ }^{123}$

While endorsing this proposal, we think that respect for domestic authority over the provision of public goods outside the TRIPS framework must ultimately rest on a more solid foundation if the WTO's own infrastructure is to become stabilized over time. Here, perhaps, another lesson to be drawn resides, by analogy, in the express list of reserved state police and welfare powers set out in article XX of the General Agreement on Tariffs and Trade.

120 See Abbott, above n 108.

121 Robert Howse, 'The Canadian Generic Medicines Panel: A Dangerous Precedent in Dangerous Times', 3 J. World Intell. Prop. (2002) 493 (criticizing the decision in Canada - Patent Protection of Pharmaceutical Products (Generic Medicines), Report of the Panel, WT/DS114/R (17 March 2000)).

122 TRIPS Agreement, above n 3, art. 8.1.

123 See Howse, above n 121 at 504. Cf. Appellate Body Report on United States - Import Prohibition of Certain Shrimp and Shrimp Products, WT/DS/26, 69 Para. 169 (12 October 1998); but see Appellate Body Report on European Communities - Measures Concerning Meat and Meat Products (Hormones), WT/DS/26, 48 Para. 123 (13 February 1998) (declining to evaluate impact of 'precautionary principle' in international law). See generally Joost Pauwelyn, Conflict of Norms in International Law: How WTO Law Relates to Other Rules of International Law (Cambridge: Cambridge University Press, 2003) 
This provision subjects state power over intellectual property laws to a criterion of 'reasonableness' when derogating from the pro-competitive mandate of the GATT. ${ }^{124}$ It further subjects the exercise of reserved state powers generally to two additional criteria, set out in the accompanying chapeau clause, namely, that resulting measures shall not to be applied in ways that 'would constitute a means of arbitrary or unjustifiable discrimination between countries where the same conditions prevail' or in ways that constitute 'a disguised restriction on international trade'. ${ }^{125}$

While the precise legal impact of these provisions on post-TRIPS state action remains to be clarified, we think they point the way to a broader principle. If the TRIPS Agreement is not to become a Trojan horse that enabled corporate distributors of private knowledge goods to disrupt the provision of global public goods, the continued exercise of WTO Members' police and welfare powers must be buttressed by an implied or express understanding that all international intellectual property standard-setting exercises presuppose a kind of de facto 'article XX' limitation in reverse. States that agree to engage in such exercises cannot thereby be tacitly understood to waive or surrender these reserved powers.

On the contrary, and in conjunction with both the Preamble to the TRIPS Agreement itself ${ }^{126}$ and article 8.1, it must be generally understood that the implementation of international IP standards is necessarily limited by criteria of reasonableness. These standards, as implemented, must not become disguised barriers to the exercise of those other police and welfare powers that are normally reserved to states. ${ }^{127}$

Where, in short, there is a conflict between private IPRs and the sovereign preservation of other public goods affecting, for example, competition, public health, sustainable agriculture, environmental protection, and the guarantees of human rights, WTO panels should respect the reserved powers of states unless they had expressly delegated their regulatory powers to some international authority or otherwise explicitly bargained them away. In the presence of any such conflict, moreover, WTO tribunals should place the burden of proof on states defending private claimants to show that their interpretation of the relevant international standards would meet these

\footnotetext{
124 See GATT 1994, above n 42, art. XX(d).

125 See id, art. XX.

126 'Recognizing the underlying public policy objectives of national systems for the protection of intellectual property, including developmental and technological objectives.' TRIPS Agreement, above n 3, Preamble.

127 Cf. J. H. Reichman, 'Securing Compliance with the TRIPS Agreement after U.S. v India', 1 JIEL (1998) 585, 594-97 (discussing mix of national autonomy and IPR agreements in Appellate Body's decision in India - Pharmaceutical Patents decision); Graeme B. Dinwoodie, 'The Architecture of the International Intellectual Property System', 77 Chicago-Kent L. Rev. (2002) 993, 1005-06; R. Okediji, 'Public Welfare and the Role of the WTO', above n 90, at 870-72.
} 
limiting criteria and would not unreasonably compromise the provision of public goods otherwise reserved to states.

\section{BALANCING PUBLIC AND PRIVATE INTERESTS IN AN EMERGING TRANSNATIONAL SYSTEM OF INNOVATION}

All countries could benefit from a functionally efficient transnational system of innovation if low barriers to entry enabled entrepreneurs anywhere to invest in the production and distribution of knowledge goods. The reduction of trade barriers, the broadening of global capital markets, and the relative harmonization of intellectual property standards could then channel the flow of investments to innovators wherever they were situated and enable them to access and utilize the technological inputs they needed, whether by purchase or license. These same investors could then export the resulting knowledge goods in the relative security that international minimum standards of IP law would protect their respective lead time advantages against free riding duplicators who contributed nothing to the collective costs of research and development (R\&D). ${ }^{128}$

In such a system, public safeguards should also enable digital telecommunications networks to link the providers of scientific and technical inputs in an endless research commons. ${ }^{129}$ Global incentives to innovate would then reward entrepreneurs who converted these inputs into value-adding, followon applications with unprecedented transnational payoffs.

In practice, however, economic realities in the post-TRIPS environment may differ significantly from these potential outcomes. ${ }^{130}$ Objective difficulties of accessing technical information generated abroad and of adapting it to local conditions still hamper the catch-up activities of firms in developing countries. International IP standards augment these difficulties by elevating the cost of inputs and by making the task of reverse engineering by honest means more costly and sometimes impossible. Additional obstacles arise when high prices charged for foreign technologies make locally produced goods uncompetitive, when foreign suppliers refuse to license needed technology at all, or when they impose unreasonable terms and conditions that restrict exports and otherwise create barriers to entry. ${ }^{131}$

128 See e.g., Keith E. Maskus, above n 8, at 192-94; J. H. Reichman, 'Universal Minimum Standards of Intellectual Property Protection under the TRIPS Component of the WTO Agreement', in Carlos M. Correa and A. Yusuf Abdulqawi (eds), Intellectual Property and International Trade: The TRIPS Agreement (1998) 21-92.

129 See e.g., Reichman and Uhlir, above n 28, at 356-60; see generally Laurence Lessig, The Future of Ideas: The Fate of the Commons in a Connected World (2002).

130 See e.g., CIPR, above n 10, at 20-29; Peter Drahos, Developing Countries, above n 5; Ullrich, above n 45 .

131 See e.g., CIPR, above n 10, at 24-26; John Barton, 'Integrating IPR Policies in Development Strategies', above n 58, at 60-64; Carlos M. Correa, 'Can the TRIPS Agreement Foster Technology Transfer to Developing Countries?’, above n 29. 
We do not mean to overstate the case or to sound unduly pessimistic. The reform of the worldwide intellectual property system has undoubtedly improved the infrastructure supporting the exchange of knowledge goods, and researchers have begun empirically to evaluate the positive contribution to economic growth this makes possible. ${ }^{132}$ The case of the Indian software industries, for example, shows just how fast small- and medium-sized industries in developing countries can catch up once the relevant technical know-how becomes embedded in an appropriate commercial environment. ${ }^{133}$ Impressive technological gains have also occurred in many other countries, including Brazil, China, and South Africa.

The point is that, as a rudimentary transnational system of innovation begins to take shape, it consists of many different components at different levels of development whose intellectual property needs and interests vary considerably. If, indeed, one looks beyond the North-South conflict of interests that informed yesterday's debates about IP standards, one might better view the developing countries today as territorial economic arenas in which a proportionately larger collection of small- and medium-sized entrepreneurs operate without the benefits of basic research results available to their counterparts in developed countries.

While the technical expertise of such firms lags well behind that of similarly sized firms that drive innovation in, say, the United States, these are differences of degree, not kind. All such firms tend to have more in common with each other than they do with the large multinational companies that are often not very innovative at all, but mainly powerful distributors of innovation originating from smaller, more dynamic firms.

Like the biggest firms, small- and medium-sized entrepreneurs - wherever situated - need IPRs to appropriate the fruits of their investments at home and to facilitate sales, licensing, and direct investments abroad. They also need these rights to defend themselves from the predatory practices of the large multinationals. ${ }^{134}$ However, these firms would logically oppose the drive for TRIPS-plus levels of intellectual property protection that tended to expand and multiply exclusive rights, limit access to the research commons,

\footnotetext{
132 See Maskus, above n 8; Arora et al., above n 26.

133 These industries benefited particularly from a previous brain drain and from the resulting return of know-how to the poorer country of origin. Moreover, much of the basic research results emanating from government-funded scientific and educational institutions in developed countries, particularly the United States, do become at least nominally available through digital telecommunications networks to scientists, innovators, and entrepreneurs even in the poorest and most remote countries. See generally Reichman and Uhlir, above n 28, Part II (mapping the public domain for research results, and describing the legal infrastructure that supports it). Skills needed to adapt such results to the production of locally suitable knowledge goods are obtainable on the international labor market, and they seem likely to emerge on local labor markets as well in response to the heightened production of such goods.

134 See e.g., Herbert Hovenkamp, Mark Lemley, and Mark Janis, 'Anticompetitive Settlements of Intellectual Property Disputes', 87 Minn L. Rev. 1719 (2003).
} 
and diminish the space for reverse engineering or other pro-competitive strategies built around value-adding applications of new technologies. ${ }^{135}$

\section{A. Developing countries as defenders of the competitive ethos}

Because a disproportionately large number of such entrepreneurs may be located in developing countries, governments in those nations could become the defenders and promoters of a transnational system of innovation in which properly balanced intellectual property rights were not ends in themselves, but rather the means of generating more scientific and technical inputs into a healthy competitive environment. To the extent that these governments represented the interests of both consumers and follow-on innovators, they would want to maintain the flows of publicly available scientific and technical information that traditionally fueled innovation in the United States; to preserve and strengthen the rights to reverse-engineer routine innovations by proper means; to foster the exchange of technical know-how between innovators at work on common technical trajectories; and to ensure that regulatory solutions to overcome market failure did not create barriers to entry or otherwise impoverish the public domain. ${ }^{136}$

To this end, the developing countries need to integrate the international IP standards codified during the Uruguay Round into their national and regional systems of innovation in ways that maximize the benefits and minimize the social costs. This difficult and financially burdensome task requires them to master and defend the flexibilities still residing in the TRIPS Agreement; to match those flexibilities with their respective, often widely different innovation assets and other comparative advantages; and to forge a procompetitive strategy with respect to the technologically more advanced countries, within the confines that the WTO Agreement makes legally possible. $^{137}$

To succeed in this endeavor, there are at least three necessary, if not sufficient pre-conditions. First, developing countries as a group need to halt or opt out of new international intellectual property standard-setting exercises that would only complicate their task and narrow their options. Second, they will need to rationalize their decision-making and interagency governance structures so as to coordinate the activities of their intellectual property bureaux with policy decisions affecting the design of their national systems of innovation. Third, they will have to dedicate significant efforts and resources to conserving and promoting those public goods that are increasingly undersupplied in developed countries but that remain indispensable to rapid technological and overall social progress in developing countries.

\footnotetext{
135 See e.g., Carlos M. Correa, 'Internationalization of the Patent System', above n 22, at 544-49.

136 See e.g., UNCTAD, The TRIPS Agreement and Developing Countries, 15-28 (1996).

137 See generally Reichman, 'From Free Riders to Fair Followers', above n 20.
} 


\section{A moratorium on stronger international intellectual property standards}

Building an effective transnational system of innovation is a sobering task because the choice and disposition of optimal incentive structures have become increasingly uncertain in both theory and practice, especially as regards new technologies, ${ }^{138}$ and because neither high-protectionist interests in developed countries nor low-protectionist interests in developing countries could be expected to advocate principles appropriately balancing the needs of innovators with those of followers. ${ }^{139}$ From this perspective, further harmonization is not an improper goal, but rather a premature exercise under the new and uncertain conditions that attend the development of cutting-edge technologies generally and information-based technologies in particular.

Here the single most daunting problem is how to allocate public and private interests in such goods, given that their raw materials - information necessarily perform a dual function as both outputs and inputs of a 'cumulative and sequential' innovation process. ${ }^{140}$ As matters stand, the complex nature and pace of cutting-edge innovation so outstrips the conventional assumptions of the patent and copyright paradigms handed down from the nineteenth century that disinterested economists and policymakers in the most technologically advanced countries lack both the experience and the evidence to draw these lines with confidence.

Contrary to the special interests' relentless propaganda, in other words, intellectual property law has not arrived at the end of history. On the contrary, the turmoil generated by the TRIPS Agreement and its aftermath, including the WIPO Copyright Treaties, ${ }^{141}$ suggests that we stand at the threshold of an era in which unanswered questions about the role of IPRs in a networked information economy demand a lengthy period of 'trial and error' experimentation, like that which ensued after the adoption of the Paris and Berne Conventions in the 1890s.

In order to validate empirically the loose claims made for and against different modes of protection, we will thus need a period of time in which

138 Compare, e.g., Richard Epstein, 'Steady the Course: Property Rights in Genetic Material', in Perspectives on Properties of the Human Genome Project, above n 49 at 153-93, with Rochelle Cooper Dreyfuss, 'Varying the Course in Patenting Genetic Material: A Counter-Proposal to Richard Epstein's Steady Course', in Perspectives on Properties of the Human Genome Project, above n 49 at 195-208 and Reichman, 'Saving the Patent System from Itself', above n 49. See generally Dan L. Burk and Mark A. Lemley, 'Policy Levers in Patent Law', 89 Virginia L. Rev. (2003) 1575.

139 See esp. Okediji, 'Public Welfare and the Role of the WTO', above n 90, at 825-72 (discussing some theoretical implications of multilateral IP negotiations).

140 See e.g., Niva Elkin-Koren, 'A Public Regarding Approach to Contracting over Copyrights', in Expanding the Boundaries of IP, above n 41, at 191, 195-98; Richard R. Nelson, 'Intellectual Property Protection for Cumulative Systems Technology', 94 Colum. L. Rev. 2674 (1994); J. H. Reichman and Jonathan Franklin, 'Privately Legislated Intellectual Property Rights: Reconciling Freedom of Contract with Public Good Uses of Information', 147 U. Pa. L. Rev. (1999) 875, 88499.

141 See above n 6. 
states at different levels of development accommodate existing international standards to their own nascent or evolving systems of innovation. ${ }^{142}$ This would yield a new body of 'laboratory effects', to use Ladas's phrase, with which to compare and test different development strategies. ${ }^{143}$ In the long run, the resulting empirical data could make it possible for states to trade further intellectual property concessions on a win-win basis, without coercion and with fewer risks that powerful interest groups had rigged the rules to lock in fleeting competitive advantages.

The time has come, in short, to take intellectual property off the international law-making agenda and to foster measures that better enabled developing countries to adapt to the challenges that prior rounds of harmonization had already bred. ${ }^{144}$ Such a moratorium would then enable both high and low protectionist countries to test their respective strategies against actual results without fear that the market openings nominally available to developing country entrepreneurs would be foreclosed by premature, ill-advised, or unbalanced efforts to re-regulate that same marketplace at their expense.

A 'time out' along these lines would make it possible, for example, to evaluate growing fears that overprotection of research results in developed countries will produce anti-commons effects and lost competitive opportunities likely to retard the pace of innovation over time. It would allow room for any countries so inclined to experiment with alternative forms of protecting investment, including proposals for more open-source initiatives ${ }^{145}$ and for compensatory liability regimes that could reconstitute the shrinking semicommons that historically mediated between exclusive intellectual property rights and the public domain. ${ }^{146}$ It would allow time for the worldwide scientific community to reformulate its data exchange policies and to reconstruct contractually the public domain for scientific and technical information that has recently come under a privatizing assault. ${ }^{147}$

142 Accord: John F. Duffy, 'Harmony and Diversity in Global Patent Law', 17 Berkeley Tech. L. J. (2002) 685, 709-25; see also Boyle, 'Enclosing the Genome', above n 49.

143 Stephen P. Ladas, Patents, Trademarks and Related Rights - National and International Protection (1975) 9-16; see also Graeme B. Dinwoodie, 'A New Copyright Order: Why National Courts Should Create Global Norms', 149 U. Pa. L. Rev. (2000) 469, 514-15; Graeme B. Dinwoodie and Rochelle Cooper Dreyfuss, 'International Intellectual Property Law and the Public Domain of Science' [this symposium].

144 Cf. S. P. Ladas, above n 143, at 15 (criticizing 'trend toward viewing "harmonization" as a good thing no matter what the problems are, as an end in itself' and stressing costs to single nations that may make it 'simply undesirable or impracticable').

145 See e.g., Yochai Benkler, 'Coase's Penguin', 112 Yale L. Rev. (2002) 369; see also Creative Commons (http://www.creativecommons.org).

146 Reichman, 'Green Tulips', above n 71; Tracy Lewis and J. H. Reichman, 'Using Liability Rules to Stimulate Local Innovation in Developing Countries', in International Public Goods and Intellectual Property, above n 29.

147 See above nn 28 and 129 and accompanying text. 
A moratorium on stronger international intellectual property standards would especially help developing countries shift their attention and limited resources away from compliance-driven initiatives ${ }^{148}$ toward programs to potentiate their national and regional systems of innovation. It would, for example, give them time to adapt promising new initiatives to their own environments, such as programs to encourage the transfer of technology from universities and public research centers to the private sector, which have produced mixed results in the United States. ${ }^{149}$ It would also give them breathing room in which to formulate competition laws and policies rooted in fairness, in concerns to lower barriers to entry, and in the need to ensure that market-induced transfers of technology were not thwarted by refusals to deal and unreasonable licensing terms or conditions. ${ }^{150}$

Efforts to institute such a moratorium could, however, run up against legitimate concerns in developed countries to prohibit free riding on investments in new technologies that enter the global marketplace. Developing countries that demand a moratorium on stronger intellectual property standards must therefore remain willing to oppose free-riding practices that undermine incentives to invest in new technologies everywhere. ${ }^{151} \mathrm{~A}$ willingness to accommodate legitimate concerns about free riding could defuse potentially heated conflicts and remove controversial topics, such as database protection, from a more ambitious standard-setting agenda. ${ }^{152} \mathrm{It}$ would also reinforce the credibility of a demand for a moratorium on further harmonization efforts by accompanying it with a 'clean hands' doctrine that would reassure investors in all countries.

\section{An institutional infrastructure for reconciling existing IPRs with national and regional systems of innovation}

The minimum international standards of intellectual property protection already mandated by the TRIPS Agreement are not uniform law, and WTO Members retain considerable flexibility in the ways those standards can be

148 See e.g., Peter Gerhart, 'Why Lawmaking for Global Intellectual Property Is Unbalanced', 22 European International Property Review (2000) 309; Symposium, 'Beyond the Treaties: A Symposium on Compliance with International Intellectual Property Law', 32 Case W. Res. J. Int'1 L. (2000) 357.

149 See Rai and Eisenberg, above n 104.

150 See e.g., Hanns Ullrich [this symposium], above n 45.

151 It was a failure to recognize a need to protect research and development investments in innovative technologies against unbridled free riding that led developed countries to demand adoption of the TRIPS Agreement within the WTO framework in the first place. See, e.g., Gail E. Evans, 'Intellectual Property as a Trade Issue: The Making of the Agreement on Trade Related Aspects of Intellectual Property', 18 World Competition, Law and Economics Review (1994) 137. This mistake should not be repeated.

152 See e.g., J. H. Reichman, 'Database Protection in a Global Economy', above n 41 (proposing interim international agreement against wholesale duplication). 
incorporated into their domestic legal systems. ${ }^{153}$ The challenge for every developing country is to enact laws and implement policies that, while consistent with international minimum standards, also effectively promote national development priorities. ${ }^{154}$ In so doing, single governments should also take into account the possibilities of cooperative actions or strategies that could reduce the overall social and economic costs of compliance with those obligations for any given region as a whole.

All developing countries should accordingly consider the feasibility of establishing a high-level, permanent working group on trade-related innovation policies, which could become the focal point for interagency review with respect to the integration into domestic law of existing and evolving international legal standards affecting innovation. These working groups or advisory councils would not duplicate the activities of national IP bureaux. They should instead play a supervisory role that requires inputs from those bureaus but that subjects policy-making decisions of importance to a suitable interagency review process concerned with national development strategy. ${ }^{155}$

Each regional or sub-regional group of developing countries should also consider the feasibility of establishing a similar working group for the purposes of coordinating positions on matters of common concern. These regional councils, once established, could benefit from the pooling of resources and expertise among their members to become centers for formulating regional standards concerning IPRs and for consensus building for future bilateral and multilateral negotiations bearing on innovation policies.

153 See UNCTAD, The TRIPS Agreement and Developing Countries, above n 136, at 32; World Bank, Global Economic Prospects and the Developing Countries (2002), above n 22, at 140-44.

154 See J. H. Reichman, 'Free Riders to Fair Followers', above n 20. Mastering the legal and economic challenges of the standards mandated under the WTO Agreements further requires that countries should, in general, avoid adopting 'off the rack' model laws that may codify or embody objectives different from those likely to accommodate their own needs. See generally J. H. Reichman, Ruth Okediji and Jayashree Watal, Draft UNDP Flagship Program on Innovation, Culture, Traditional Know-How and Bioresources, prepared for the Special Unit for Technical Cooperation Among Developing Countries (TCDC), April/May 2000 [hereinafter Draft UNDP Program].

155 This proposal was first put forward in Draft UNDP Program, above n 154. The proposed interagency working groups could oversee the sustained training of cadres and updating of knowledge needed by governments to formulate policy options over time. They could also undertake the following additional endeavors:

- Coordinate activities to enable consensus building at the national level;

- Support the training and sensitization of law enforcement officials to ensure a cadre of skilled personnel in each developing country and to formulate regional enforcement standards based on national positions;

- Coordinate inter-council activities with a view to identifying best practices and models for adaptation by other countries and to facilitating consensus building at the regional level;

- Support the activities of national, regional and international nongovernmental organizations (NGOs), which identify with the mission of the advisory councils.

See id. 
In putting forward these proposals, we make no assumptions that developing countries would think alike on the relevant issues or that members of any regional group will readily embrace a common position. The opposite is true. What experience demonstrates is that any coalition of developing country interests will be more effective than the absence of such a coalition. ${ }^{156}$ Compromise positions staked out by regional groups can block the most egregious proposals emanating from special interest coalitions, and can sometimes even lead to universally valid intellectual property legislation of value to the developing countries. ${ }^{157}$

The organization of national and regional interagency working groups would reduce the dependence of developing countries on ad hoc support by foundations, NGOs, and pro bono legal counsel. The existence of such organizations would further ensure early detection of new protectionist initiatives, facilitate prompt reactions to them, and enable the formation of coalitions to resist them if undesirable or to modify and support them if desirable. It would also make it possible to appoint subcommittees that could follow ongoing initiatives at WIPO and the WTO, and support the work of permanent delegations and regional political caucuses at these and other intergovernmental organizations on a continuing basis.

Above all, the existence of national and regional working groups on traderelated innovation policies would enable developing countries to formulate broad-based strategies to resist pressures at the bilateral and multilateral levels for undesirable demands for protection. Collective action to resist such pressures seems more likely to succeed than leaving each state to fend for itself, in which case there is simply no institutional infrastructure for promoting a systematic and coordinated response to what has become a systematic and coordinated drive to re-regulate the global economy.

\section{B. Maintaining the supply of knowledge as a global public good}

Critical to the future success of an emerging transnational system of innovation is its ability to ensure the production and adequate supply of needed public inputs known to have fueled the production of private knowledge goods in the technologically most advanced economies. ${ }^{158}$ This topic is relatively new and extremely complex, and the need for collective international action has been inadequately studied.

156 See e.g., Abbott, 'The Future of IPRs', above n 53, at 42-43; Okediji, above n 90, at 842-61 (discussing role of coalitions in TRIPS negotiations).

157 See e.g., Pamela Samuelson, 'The U.S. Digital Agenda at WIPO', above n 6.

158 See e.g., Michael Callon, 'Is Science a Public Good?', 19 Sci. \& Hum. Values (1994) 395, 400; Nelson, 'The Market Economy and the Scientific Commons', above n 76; David, above n 53; Stiglitz, 'Knowledge as a Public Good', above n 51. 


\section{Dynamic properties of knowledge as a global public good}

In thinking about the uncertain properties of knowledge as a global public good, the intimate and complex relationship between knowledge and trade requires particular attention, especially in light of the TRIPS Agreement and related issues that were previously discussed. In principle, international trade law rooted in the GATT and the WTO Agreement should stimulate worldwide competition in the provision of goods and services generally, including knowledge goods. At the same time, qualitative leaps in knowledge as a product of aggregate investment in $\mathrm{R} \& \mathrm{D}$ also depend on private intellectual property rights, especially patents, which deliberately restrain trade in the short run in order to elevate the level of competition later on. ${ }^{159}$

In this process, knowledge plays at least a triple role. Existing knowledge fuels the production of additional knowledge as an input from any commons accessible to any given set of researchers or entrepreneurs. New knowledge emerges fresh from publicly supported research endeavors, often involving massive expenditures, whence it may enter a research commons, as typically occurred in the United States, or it may attract proprietary rights of either a public or private nature. ${ }^{160}$ Finally, new knowledge may come to light from privately funded research and development initiatives, or from public-private partnerships. In this form, it may or may not become available as an input for open research in the future, depending upon the modalities of intellectual property protection - including permanent rights in collections of data - that investors obtain under national and international law.

Further complicating any assessment of appropriate international action affecting the provision of knowledge as a global public good is the fact that its positive role in domestic systems of innovation, though palpable and universally recognized, is not well understood nor fully elaborated. Nor do the most successful systems of innovation demonstrate any common or universal set of practices in this respect that could readily be transcribed to the international level.

In the United States, for example, especially during the Cold War period, massive amounts of federal money were spent on producing data and research, usually through universities and other scientific institutes. Under traditional US law, all government-generated data automatically entered the public domain, where this gave a huge fillip to both public and private research. Most publicly funded research results likewise became widely

159 John H. Barton, 'The Economics of TRIPS: International Trade in Information Intensive Products', 33 Geo. Wash. Int'l Rev. (2001) 473, 486-91 (stressing tradeoffs between short-term costs to consumers in higher prices and long term benefits through increased innovation).

160 See E.C. Database Directive, above n 77; Reichman and Uhlir, above n 28, at 325-50. The tendency of intellectual property rights to make new knowledge artificially scarce in order to reward investors then impacts on the provision of other public goods, including free trade, the preservation of the natural commons or efforts to promote public health, in ways that, as previously discussed, may trigger resentment and public outcry around the world. See above text accompanying nn 28 , $129,152$. 
available under both the sharing ethos of science and 'open access' policies that federal funding agencies imposed. ${ }^{161}$

Recently, however, funds for government-generated data have shrunk; and there is a growing tendency for government agencies to license such data from the private sector under increasingly restrictive conditions. Moreover, government-funded research results are increasingly transferred to the private sector under exclusive patent rights, ${ }^{162}$ made possible by the Bayh-Dole Act of $1980 .{ }^{163}$ New IPRs in digital transmissions and collections of data may further augment the privatization of government-funded research at the expense of the scientific community's sharing ethos and traditional open access policies. ${ }^{164}$

In the European Union, in contrast, government-generated data were traditionally subject to exclusive property rights, and some recent research suggests that this practice greatly hampered development in some sectors, such as weather-related innovation. ${ }^{165}$ At the same time, government-funded research in the EU is increasingly likely to be transferred to the private sector through patents, while all collections of data - including publicly funded data - have become subject to powerful and potentially permanent exclusive property rights under the EC Directive on Databases of $1996 .{ }^{166}$ The impact of these measures on overall research and development in the EU remains to be seen, but the scientific community there has voiced growing concerns. ${ }^{167}$

Practices with respect to the provision of knowledge as a public good in developing countries are quite different and even harder to evaluate. Here there has always been a disproportionately large reliance on the public sector, with uneven but sometimes commendable results. ${ }^{168}$ However, efforts to open up previously 'command economies' to private enterprise in these countries have put new pressures on existing modes of producing knowledge goods in the public sector, and new modes of transferring knowledge from the public to the private sector are badly needed in any case. As the drive to stimulate investments in private research and development acquires momentum in more developing countries, careful thought will have to be given to

161 See generally Reichman and Uhlir, above n 28, at 325-50.

162 See id, at 366-71; Rai and Eisenberg, 'Bayh-Dole Reform', above n 104.

163 Act of December 12, 1980, Pub. L. No. 96-517, 6(a), 94 Stat. 3015, 3019-28 (1980) (codified as amended at 35 U.S.C. 200-212 (1994)).

164 See Reichman and Uhlir, above n 28, at 361-415.

165 Peter Weiss, 'Conflicting International Public Sector Information Policies and Their Effects on the Public Domain and the Economy', in Role of Scientific and Technical Data, above n 28, at 129-32.

166 See above $\mathrm{n} 77$.

167 Paul A. David, 'Will Building “Good Fences” Really Make “Good Neighbors” in Science? Digital Technologies, Collaborative Research on the Internet and the EC's Push for the Protection of Intellectual Property' (Stanford Institute for Econ. Pol'y Res., Discussion Paper No. 00-33, 2000) [hereinafter, David, 'Good Fences'] available at http://ssept.stanford.edu/papers/pdt/00-33.pdt. See also Royal Society Report, above n 78.

168 See e.g., Helfer, above n 57. See also Cottier and Panizzon, above n 117. 
preserving and enhancing a public sector research infrastructure that was formerly taken for granted.

This brief survey confirms that ensuring the provision of knowledge as an essential public good in an incipient transnational system of innovation would be extremely difficult to manage under the best of circumstances owing to the diversity of practices among existing systems and to the changes underway within these systems. This task is made still more difficult by relentless pressures to ratchet up international standards of intellectual property protection without regard to, and often at the expense of, traditional modes of generating knowledge as a public good.

This one-sided push for privatization requires a collective response aimed at preserving the roles of both knowledge and competition as international public goods. Calibrating this response, however, is difficult precisely because national experiences in technology-exporting countries are both diverse and changing, while the challenge and problems of protecting investment in cutting-edge technologies today makes reliance on even the most successful national solutions of the past problematic.

\section{Nurturing a transnational system of innovation}

This perplexity gives rise to a troubling conundrum. Without an organized, collective movement to promote and enhance the supply of knowledge as a public good, the transnational system of innovation taking root in the wake of the TRIPS Agreement could become suboptimal and skewed from the outset. Yet, without a lengthy period of experimentation in both developed and developing countries, policymakers lack the experience and data to confidently design the balance of public and private interests that should prevail in that same system. This conundrum in itself constitutes a valid justification for a moratorium on international intellectual property standardsetting exercises, and it underscores the need for national and regional experiments that could shed more light on how a transnational market for knowledge goods should ultimately be structured.

To the extent that developing countries could successfully ensure that their respective systems of innovation promoted healthy competition in knowledge goods while otherwise delivering an adequate supply of public goods, they could more readily and capably articulate these same interests in multilateral negotiations affecting the future shape of a transnational system of innovation. This experience would arm them with serious counter-proposals to avoid the excesses of intellectual property protection that some developed countries have embraced.

The long-term prospects for an emerging worldwide system of innovation ultimately depend on the level of investment it attracts, on the quantity and quality of innovation it stimulates, and on the degree of healthy competition it sustains. While intellectual property law will necessarily play a crucial role in attaining positive outcomes, such a system cannot fulfill its promise if it 
becomes prematurely shackled by the intellectual property policies and norms favored by any particular group of powerful companies or countries. On the contrary, the evidence shows that small- and medium-sized companies continue to generate the bulk of real technological advances, ${ }^{169}$ and any regulatory scheme developed for this system must take their needs and interests into account.

Pro-competitive pressures generated from within the emerging transnational system of innovation could then reverberate upon highly protectionist national systems in developed countries. They could embolden, if not empower, coalitions of small- and medium-sized entrepreneurs there to seize the political initiative and recalibrate the balance of public and private interests in their domestic intellectual property regimes.

It is well to remember that the law and economics disciplines still know relatively little about how an incipient transnational system of innovation should best be organized and regulated in the short and medium terms. Countries big and small, rich and poor, find themselves at the start of a new era, in which serious thought and bold experimental undertakings will be needed to identify the optimal mix of public and private goods in this broadened but largely uncharted domain. The one sure conclusion that follows from this analysis is that hardening past experience into possibly flawed international rules to regulate this emerging transnational system should be avoided. What is needed, instead, is a long period of experimentation under pro-competitive conditions that could yield instructive 'laboratory effects' comparable to those that gradually led to the progressive development of international intellectual property law after the Berne and Paris Conventions - the 'Great Conventions' - were established in the 1890s.

169 See most recently Josh Lerner, 'The New New Financial Thing: The Sources of Innovation Before and After "State Street", N.B.E.R. Working Paper No. W10223 (January 2004). 